\title{
The Issues of Antioxidant Therapy
}

\author{
Boris V. Nemzer ${ }^{1 *}$, Alexander Y. Yashin ${ }^{2}$, Yakov I. Yashin ${ }^{2}$ \\ ${ }^{1}$ Department of Research \& Development, VDF FutureCeuticals, Inc., Momence, IL, USA \\ ${ }^{2}$ Scientific Research Center "Chromatographia", Moscow, Russia \\ *Corresponding Author \\ Boris Nemzer \\ Director of Research and Development \\ FutureCeuticals, Inc. \\ Momence, IL 60954 USA \\ Email: bnemzer@vandrunen.com
}

Received: 02 February 2013; $\mid$ Revised: 25 February 2013; $\mid$ Accepted:20 March 2013

\section{Abstract}

Interest in antioxidants and antioxidant therapy has been growing during the last decade. Antioxidants are generally considered to have the capability to protect people from harmful effects of reactive oxygen and nitrogen species (RONSs), including free radicals (FR), when these are present in excessive amounts. RONS and free radicals perform a variety of useful biological functions in the body. Their excess is controlled by a natural antioxidant protection system in humans. This protection is provided at three levels: by simple molecules (such as cysteine, glutathione (GSH), uric acid, ubiquinol, etc.), medium-molecular weight, and high molecular weight compounds (enzymes, etc.). Under certain adverse conditions, this system does not manage to provide adequate protection and the RONSs and free radicals begin to damage vital DNA, proteins, and lipids. In such a case, antioxidant therapy, which includes antioxidant supplements and foods containing natural antioxidants, has been suggested to be of possible benefit. However, there are many unresolved issues related to the effective use of an antioxidant therapy:

1. A person should know the content of antioxidants in everyday food products and its relation to the storage time and processing methods used.

2. How many antioxidants should a person consume? It is known that at high concentrations some antioxidants become pro-oxidants.

3. Are the antioxidants consumed by a person bioavailable and, if so, to what extent; for some food products, bioavailability has already been determined but most foods have not been examined.

4. Many antioxidants are digested by intestinal microflora before they reach the systemic blood circulation.

5. Even those antioxidants that do reach the blood are often rapidly metabolized; the role of their metabolites is unclear; there is some evidence that certain metabolites are also antioxidants.

6. How long do antioxidants and their metabolites stay in the body; how are they distributed in different organs; and when are they excreted? In order to answer these questions, the pharmacokinetics of antioxidants should be studied.

7. The presence of oxidative stress, i.e., excess amounts of RONSs and free radicals, can be detected by various oxidative stress markers but, in order to see the whole picture, the actual concentrations of RONSs 
and free radicals should also be monitored. In vivo determination of RONSs and free radicals is almost never conducted.

All these questions must be addressed in order to provide appropriate antioxidant therapy. This could be extremely important because it could be used to detect and even prevent diseases at early stages of development.

Keywords: Antioxidants, antioxidant therapy, oxidative stress, free radicals, polyphenols, diet.

\section{Introduction}

In recent years, there has been growing interest in antioxidant therapy. Several comprehensive reviews [1-10] and books [11-13] have been published, and the International Symposium on Antioxidants in Nutrition and Therapy and the International Conference on Polyphenols and Health has regularly been meeting.

One book presents the results of studies devoted to investigating the health of the longest lived people on Earth - the residents of Okinawa in Japan-conducted over 25 years [11]. Among other factors, consumption of food and beverages that are high in antioxidants is one of the reasons for their longevity. The Okinawans have the highest content of flavonoids in their blood -50 times higher than that of the Europeans [11].

Antioxidant therapy should be administered to healthy people who are diagnosed with oxidative stress, and to patients whose diseases are accompanied by oxidative stress. Antioxidant therapy includes special antioxidant medicine, as well as special foods and dietary supplements. Prescription of clinical antioxidant therapy requires knowledge of antioxidant content in food, antioxidant activity and bioavailability (biopermeability), as well as analytical monitoring over the course of the antioxidant therapy.

Table 1. Databases on Polyphenol Antioxidants in Foods

\begin{tabular}{|l|l|l|c|}
\hline \multicolumn{1}{|c|}{ Name/Developer } & \multicolumn{1}{|c|}{ Comment } & Reference \\
\hline 1 & Antioxidant Food Database & $\begin{array}{l}\text { More than 3,100 foods, beverages, } \\
\text { spices, herbs, and supplements used } \\
\text { worldwide. }\end{array}$ & 14 \\
\hline 2 & $\begin{array}{l}\text { Databank for Total Content of } \\
\text { Antioxidants, Khimavtomatika Scientific } \\
\text { Development \& Production Center }\end{array}$ & $\begin{array}{l}\text { More than 1,000 products (foods, } \\
\text { beverages, supplements, multivitamins, } \\
\text { medicines, herbal extracts, etc.) }\end{array}$ & 15,16 \\
\hline 3 & $\begin{array}{l}\text { USDA (United States Department of } \\
\text { Agriculture) Database for the Flavonoid } \\
\text { Content of Selected Foods (2009) }\end{array}$ & 26 flavonoid aglycones from 231 foods. & 17 \\
\hline 4 & \begin{tabular}{l} 
Phenol-Explorer Database \\
\hline 5
\end{tabular} & $\begin{array}{l}\text { EuroFIR-BASIS } \\
502 \text { polyphenols from 452 foods. }\end{array}$ & 18 \\
\hline
\end{tabular}




\section{Databases on antioxidants in foods.}

In order to administer antioxidant therapy, it is necessary to know the content of antioxidants in foods, beverages, dietary supplements, etc. There are hundreds and thousands of publications on the quantification of antioxidants in various products, and on determination of their antioxidant activity.

In the last decade, several databases were created in various countries on the content of polyphenol antioxidants - the major ones are listed in Table 1 [14-19]. Information on other databases on polyphenols and their health promoting effects is presented in one of the published reviews [10].

\subsection{Antioxidant Food Database}

One database presents the content of antioxidants in the most typical food products, as well as in traditional medicinal herbs, plants, spices, and supplements (over 3,100 products in total) [14]. The antioxidants were determined by a modified FRAP assay. The FRAP assay measures antioxidants with a reduction potential below the reduction potential of the $\mathrm{Fe} 3+/ \mathrm{Fe} 2+$ couple [20]. This method cannot identify the thiol group containing antioxidants. All results obtained are included in the Antioxidant Food Table specifying the country of origin, type and name of the food product.

The foods differed in the antioxidant content by as much as a thousand times. Foods with the highest content of antioxidants include berries, fruits, nuts, vegetables, chocolate, and some beverages.

All measurements were performed in 2000 through 2008. The foods were taken from Europe, America, Asia, and Africa. The United States Department of Agriculture provided 1,113 products.

All samples were extracted with water/methanol except for the vegetable oils which were extracted with isopropyl alcohol and high-fat foods which were extracted with water/isopropanol.

Out of the total number of the examined products, 1,943 were foods of plant origin, 211 of animal origin, and 854 were mixed products.
There were 24 food categories in total. Most items of foods were examined in the following categories (number of food items is specified in parenthesis): spices and plants (425), fruit and vegetable products (303), beverages (283), fruits and fruit juices (278), grain products (227), sauces (251), berries and berry products (119), vitamins and supplements (131), nuts, grains, and seeds (90), etc.

One publication provides tables with the contents of antioxidants in beverages, nuts, grains, seeds, berries, fruits, vegetables, spices, and herbs [14]. It should be noted that data provided in this publication for coffee is significantly higher compared to tea, red wine, or pomegranate juice.

The values differed by an order of magnitude compared to the values presented in other publications $[15,17]$, in which the measurements were made by different additional methods, as well as by FRAP.

Altogether the tables contained 3,139 food items; also, information on 1,300 food items had been published previously [20].

The values for antioxidant content in meat, fish, and dairy products were lower than in other literature. This is probably related to the fact that the solvent used (isopropanol) was not the best one.

\subsection{Database on Polyphenol Content in Food and Beverages (Phenol-Explorer Database, www.phenol-explorer.eu)}

This polyphenol database was created based on analysis of over 1,000 publications devoted to the determination of polyphenols in 60,000 food items [18].

The most reliable results of 37,000 tests were selected and divided into 5 groups according to the methods of analysis:

- Chromatography - 28,739 tests

- Chromatography after hydrolysis - 5,804 tests

- Normal-phase HPLC - 488 tests

- Spectrophotometry (Folin-C assay) (total amount of polyphenols) - 2,218 articles

- Spectrophotometry (at different $\mathrm{pH}$ values) (total amount of anthocyanins) - 409 articles 
All chromatographic methods constitute about $92 \%$ of all methods used. Most of the publications (95\%) were primarily taken from journals of food science over the past 20 years, and $70 \%$ of such publications were issued in the last 10 years.

In total, 502 polyphenol antioxidants were determined in 452 different products including 277 flavonoids, 108 phenolic acids, 30 lignans, 10 stilbenes, and 80 other polyphenols.

Polyphenolic forms included aglycones, glycoside derivatives, and esters.

Food items were classified into 9 groups (non-alcoholic beverages - 65, alcoholic beverages - 19, fruits and fruit products - 103, vegetables -72 , grain products -21 , nuts -65 , cocoa - 3, condiments -87 , and vegetable oils 10). Numbers above indicate the number of products in each group.

The amounts of different polyphenols found in these groups are:

- Non-alcoholic beverages: 105 flavonoids, 49 phenolic acids, and 20 other polyphenols;

- Fruits: 112 flavonoids, 47 phenolic acids, and 14 other polyphenols;

- Alcoholic beverages: 75 flavonoids, 33 phenolic acids, and 39 other polyphenols;

- Vegetables: 92 flavonoids, 51 phenolic acids, and 18 other polyphenols;

- Grain products: 33 flavonoids, 29 phenolic acids, and 8 other polyphenols;

- Nuts: 76 flavonoids, 16 phenolic acids, and 25 other polyphenols;

- Cocoa: 25 flavonoids, 13 phenolic acids, and 7 other polyphenols;

- Condiments: 62 flavonoids, 29 phenolic acids, and 26 other polyphenols;

- Vegetable oils: 11 flavonoids, 28 phenolic acids, and 36 other polyphenols.

Food items containing the highest amounts of polyphenol antioxidants are: black currant, cocoa, dark chocolate, nuts, orange juice, grape juice, artichokes, black olives, red onion, spinach, soybeans, red raspberries, coffee, tea, red chicory, red wine, red currants, vegetable oils, blueberries, broccoli, cranberries, pomegranate juice, etc. $56 \%$ of individual polyphenols are found in trace amounts (no more than $1 \mathrm{mg} / 100 \mathrm{~g}$ or
$1 \mathrm{mg} / 100 \mathrm{l}$ ), some polyphenols are found in the amounts of $500-700 \mathrm{mg} / 100 \mathrm{~g}$.

The richest sources of flavanols (in $\mathrm{mg} / 100 \mathrm{~g}$ ) are: cocoa $(3,411)$, dark chocolate $(1,590)$, aronia berries (659), blueberries (330), black currants (139), strawberries (148), apples (111), different kinds of nuts (181-496), as well as green and black tea and red wine.

A high content of flavanols $(\mathrm{mg} / 100 \mathrm{~g})$ was observed in onions (yellow and red) and shallots (73-158), spinach (119), and aronia berries (188).

The main sources of flavanones are citrus fruits. Their content in fresh grapefruit, orange, and lemon juices is 46, 38, and $33 \mathrm{mg} / 100 \mathrm{ml}$, respectively.

High concentrations (mg/100 g) of hydroxybenzoic acids are contained in: chestnut (1215), raspberries (121), pomegranate juice (55), and blueberries (50). Other sources include tea, wine, figs, and berries.

The richest sources of hydroxycinnamic acids are: coffee $(212 \mathrm{mg} / 100 \mathrm{ml})$, artichokes (202 mg/100 g), prunes $(192 \mathrm{mg} / 100 \mathrm{~g})$, red chicory $\quad(183 \mathrm{mg} / 100 \mathrm{~g}), \quad$ blueberries $(135 \mathrm{mg} / 100 \mathrm{~g})$, green olives $(104 \mathrm{mg} / 100 \mathrm{~g})$, black olives (96 mg/100 g), plums (89 mg/100 g), and cherries $(88 \mathrm{mg} / 100 \mathrm{~g})$.

Among grain products, the largest amounts of these acids are present in maize $(212 \mathrm{mg} / 100 \mathrm{~g})$, whole rye grains $(136 \mathrm{mg} / 100 \mathrm{~g})$, and wheat (90 mg/100 g).

Limitations of the Phenol-Explorer database are: insufficient data on the content of proanthocyanidins in foods; little information on the content of polyphenols in different varieties of the same product.

\subsection{Database of flavonoid content in foods (USDA).}

This database specifies 26 flavonoids in 23 food products as measured by HPLC [17]. This database is updated over time. Separate databases on the content of proanthocyanidins, anthocyanins, and isoflavones in food products are planned.

This databank contains information on flavonoids contained in the following products:

- Alcoholic beverages (red wine, white wine, beer, sherry, cider, etc.) 
- Tea (black tea, green tea, oolong)

- Juices (apple, blueberry, orange, cranberry, grapefruit, lemon, grape, etc.)

- Berries (whortleberry, strawberries, blueberries, cherries, cranberries, black, red, and white currants, gooseberries, grapes, rowanberries, lingonberries, mulberries, elderberries, etc.).

- Fruits (apples of different varieties, apricots, avocados, bananas, pears, plums, nectarines, oranges, lemons, mangos, mandarins, pummelo)

- Vegetables (potatoes, peppers, tomatoes, artichokes, asparagus, radishes, onions, peas, beetroots, broccoli, kohlrabi, Brussels sprouts, Chinese cabbage, white and red cabbage, carrots, celery, cucumbers, etc.)

- Grain products (bread, macaroni, buckwheat, rice, soya, sorghum)

- Dark chocolate, milk chocolate, cocoa powder.

The data is also provided on the content of various flavonoids in coffee, nuts, honey, mushrooms, and jams.

Some berries contain large amounts of anthocyans (anthocyanidins and anthocyanins in aggregate) $(\mathrm{mg} / 100 \mathrm{~g})$ : whortleberry - 250-500, blueberries - 100-400, cherries - 35-450, strawberries - 15-75 (the range specified is obtained from different studies).

One of the well-known and well-studied flavonols is quercetin which is found in many berries, fruits, and vegetables.

The data taken from the USDA databank on quercetin content is presented $(\mathrm{mg} / 100 \mathrm{~g})$ :

Berries: lingonberries - 21; cranberries - 14; black currants -5.7 ; white currants -1.95 ; red currants -0.95 ; blueberries -3 ; cherries -1.25 ; blackberries $\quad-\quad 1 ; \quad$ raspberries -0.8 ; strawberries -0.65 .

Fruits: apples -4.4 ; red grapes -3.5 ; black grapes -2.5 ; green grapes -0.9 ; apricots -2.5 ; grapefruits -0.4 .

Vegetables: anejo peppers -27.6 ; red onions 20 ; yellow onions - 13.3; white onions - 5.2; green onions -14.2 .

\subsection{USDA Database for the Proanthocyanidin Content of Selected Foods [17a]}

Commonly found antioxidants are flavonoids in the form of aglycones, or as derivatives associated with various sugars. Some polymerized algycone flavonoids present in foods contain 10 or even 14 polymer fragments - the so-called proanthocyanidins-which are also potent antioxidants.

The USDA Database contains information on the proanthocyanidins (PA) content of various foods as determined by HPLC. Proanthocyanidins are sub-divided into procyanidins, prodelphinidins, and propelargonidins. Procyanidins constitute the largest class of PAs, consisting exclusively of flavan-3-ols, catechins and epicatechins. Prodelphinidins are synthesized from gallocatechin and epigallocatechin units whereas propelargonidins consist of afzelechin and epiafzelechin units.

Products containing PAs can significantly contribute to antioxidant therapy. Table 2 provides a list of products that contain the greatest amount of PAs. The top PA content is found in cocoa beans and cocoa productswherein PA content ranges from 1-10\%. Among berries with the highest PA content are cranberries, blueberries, strawberries, black currants, and cherries. It is worth noting that wild blueberries contain twice as much PAs as cultivated blueberries (Table 3). A significant amount of PAs is contained in some fruits, such as plums, peaches, and pears (Table 4). Some nuts are a very good source of PAs, with hazelnuts and pecans being ahead of the competition (Table 3). Apples can make a great contribution to antioxidant therapy because they are typically consumed in quite large quantities in all countries. Table 4 shows, first of all, that the PA content in different apple varieties can vary by up to 3 times, and secondly, more PAs are contained in apple peel than in apple flesh.

Additional food products with a high PA content, beyond those listed in Tables 1 through 3 , include hops - 293.16; barley - 99.24; buckwheat flour - 50.3; buckwheat hulls - 44.51; some spices, such as curry powder -74.16 , etc. 
Table 2. List of Food Products with the Highest Content of Proanthocyanidins

\begin{tabular}{|l|l|l|}
\hline No. & Product Name & $\begin{array}{l}\text { Content, } \\
\mathrm{mg} / 100 \mathrm{~g}\end{array}$ \\
\hline 1 & Cacao beans & 9481.75 \\
\hline 2 & Spices, cinnamon, ground & 7908.14 \\
\hline 3 & Sorghum, bran & 4604.07 \\
\hline 4 & Sorghum, grain & 1902.38 \\
\hline 5 & Baking chocolate & 1635.94 \\
\hline 6 & Chocolate, liquor & 1476.67 \\
\hline 7 & Cocoa, dry powder & 1373.32 \\
\hline 8 & Beans, pinto & 737.27 \\
\hline 9 & Choke berries & 663.7 \\
\hline 10 & Cranberries & 418.77 \\
\hline 11 & Beans, kidney & 410.25 \\
\hline 12 & Grape seeds & 373.4 \\
\hline 13 & Blueberries, wild & 328.63 \\
\hline & & \\
\hline
\end{tabular}

Table 3. Food Products Containing Proanthocyanidins

\begin{tabular}{|l|l|l|}
\hline No. & Food Products & $\begin{array}{l}\text { Content, } \\
\mathrm{mg} / 100 \mathrm{~g}\end{array}$ \\
\hline & Berries & \\
\hline 1 & Cranberries & 418.77 \\
\hline 2 & Blueberries, wild, raw & 328.63 \\
\hline 3 & Cherries, sweet & 191.3 \\
\hline 4 & Blueberries, raw & 176.5 \\
\hline 5 & Currant, black & 158.03 \\
\hline 6 & Strawberries & 141.87 \\
\hline 7 & Raspberries & 25.07 \\
\hline 8 & Blackberries & 23.31 \\
\hline
\end{tabular}

\begin{tabular}{|c|c|c|}
\hline 9 & Currant, red & 5.13 \\
\hline & Fruit & \\
\hline 1 & Plum, black diamond & 247.27 \\
\hline 2 & Plum, with peel & 220.78 \\
\hline 3 & Peaches, yellow & 71.75 \\
\hline 4 & Pear, green cultivars & 42.3 \\
\hline 5 & Pear, red Anjou & 31.92 \\
\hline 6 & Peaches, white & 29.76 \\
\hline 7 & Nectarines & 29.18 \\
\hline 8 & Plum, yellow & 27.71 \\
\hline 9 & Kiwi, gold & 13.93 \\
\hline 10 & Mangos & 12.7 \\
\hline 11 & Apricots & 10.32 \\
\hline 12 & Avocados & 7.34 \\
\hline 13 & Bananas & 3.37 \\
\hline 14 & Pomegranates & 1.1 \\
\hline & Nuts & \\
\hline 1 & Hazelnuts (filberts) & 500.66 \\
\hline 2 & Pecans & 494.05 \\
\hline 3 & Pistachio & 237.34 \\
\hline 4 & Almonds & 184.02 \\
\hline 5 & Walnuts & 67.25 \\
\hline 6 & Cashew nuts & 8.68 \\
\hline
\end{tabular}

Note: All products were tested as raw and unprocessed materials.

2.5 Databank on the content of antioxidants in foods, beverages, and dietary supplements (Scientific and Technical Center "Chromatographia", Russia)

This databank contains the values for total antioxidant content (TAC) in foods, beverages, dietary supplements, multivitamins, herbal extracts, with over 1,100 items in total $[15,16]$. All measurements were made by an 
amperometric method which allows for selective direct identification of antioxidants only. Methods for determining water-soluble and fatsoluble antioxidants have been developed and certified. Russian State Standards (GOSTs) on determination of antioxidants in food products by the amperometric method have been issued in the Russian Federation [21].

Table 4. Content of Proanthocyanidins in Apples

\begin{tabular}{|l|l|l|l|}
\hline \multirow{2}{*}{ No. } & \multirow{2}{*}{ Apple } & \multicolumn{2}{|l|}{ Content, mg/100g } \\
\cline { 3 - 4 } & Variety & Unpeeled & Peeled \\
\hline 1 & Granny Smith & 131.01 & - \\
\hline 2 & $\begin{array}{l}\text { Red } \\
\text { Delicious }\end{array}$ & 127.79 & 90.67 \\
\hline 3 & Gala & 92.42 & - \\
\hline 4 & $\begin{array}{l}\text { Golden } \\
\text { Delicious }\end{array}$ & 83.01 & 77.53 \\
\hline 5 & Fuji & 65.59 & - \\
\hline 6 & Reinette & 42.88 & - \\
\hline
\end{tabular}

For the first time, the total antioxidant content of fat-soluble antioxidants was determined in milk, fish and meat products as well as in various vegetable oils by the amperometric method. The total antioxidant content of fat-soluble antioxidants was also determined in cocoa and nuts.

The databank contains over 30 types of products (number of food items is specified in parenthesis): fruits (13), apples (8), berries (25), vegetables (29), potatoes (19), spices (24), green tea (29), flavored green tea (23), black tea (23), flavored black tea (12), fruit tea (47), coffee (21), instant coffee (11), kvass [rye bread drink] (10), juices (15), beverages (18), dry red wines (63), semi-sweet red wines (19), special wines (8), pink wines (3), white wines (20), cognac and brandy (39), whiskey (3), tequila (1), balms (21), beer (12), honey (108), honey products (7), grain products (12), sprouted grains and seeds (12), bread, grains, and flours (18), vegetable oils (40), dairy products (39), meat products (19), fish products, including fish eggs (14), cocoa (14), chocolate (23), nuts and seeds (12), dietary supplements (147), blueberry-based dietary supplements for eyes (12), medicines (20), multivitamins (9), medicinal plants (42), etc.

\section{Levels of antioxidant consumption in various countries}

Polyphenols (flavonoids, phenolic acids, proanthocyanidins, and ellagitannins) are beneficial for people and provide protection against chronic diseases. However, at present, a little is known about the consumption of polyphenols in different countries. In recent years, information on consumption of polyphenols in Finland, Greece, France, USA, Spain, Korea, Brazil, Denmark, Japan, Australia, the Netherlands, and some other countries has been published [22-45].

\subsection{The level of polyphenol antioxidants consumption in Finland.}

In Finland, the amount of consumed polyphenols among adults was assessed by using a special program and the Fineli Food Composition Database [42]. Over two thousand people have been surveyed. The average amount of 44 different polyphenols being consumed in food was $863 \pm 415 \mathrm{mg}$ per day. A total of 143 food products have been examined. Phenolic acids $(75 \%)$ constituted the dominant group of consumed polyphenols, whereas the minor groups included proanthocyanidins (14\%), anthocyanidins (6\%), and other flavonoids (5\%). However, the total flavonoid content including anthocyanidins, proanthocyanidin monomers, flavonols, flavanones, flavones, and isoflavonoids was $103 \mathrm{mg}$ per day. Coffee and grains were found to be primary sources for phenolic acids. Anthocyanidins, ellagitannins and proanthocyanidins were predominantly originated from berries and berry products, whereas fruits were the primary source of flavonols, flavones, and flavanones. The content of polyphenols in food products was determined by HPLC. Phenolic acids which have been determined included caffeic, ferulic, gallic, n-coumaric, and syringic acid. The caffeic and ferulic acids were the predominant components (80\%) in the pool of phenolic acids. Detected proanthocyanidins were 
shown to be in the forms of monomers, dimers, trimers, and polymers (4-10 fragments). Anthocyanidins (cyanidin and delphinidin), flavonols, and flavanones were determined among flavonoids. In addition to polyphenols, carotenoids and sterols were also determined in food products. Sixteen out of the top twenty food products with the highest content of polyphenols were berries. Among fruits, the highest levels of polyphenols were found in black plums, cherries, apples, and black grapes. Among vegetables, the highest levels of polyphenols were found in rhubarb and red cabbage. Rye bran is a good source of polyphenols among grains. Among beverages, coffee is holding the leading position in polyphenols content. It should be noted that Finland is a 'coffee' country - it holds one of the first places for coffee consumption per capita in the world ( $86 \%$ of women and $91 \%$ of men consume coffee, data from Findiet 2002).

\subsection{The level of polyphenolic antioxidants consumption in France.}

This article aimed to create a French databank on polyphenol content in fresh fruits and vegetables, and to evaluate the levels of their consumption by the population of France [22].

The Folin-Ciocalteu method adapted to fruits and vegetables has been used for determining the total phenolic concentration [46]. Vegetables such as artichokes, parsley and Brussels sprouts contained the highest levels of polyphenols (more $250 \mathrm{mg} / 100 \mathrm{~g}$ of fresh edible portion relative to gallic acid). Fruit and berries such as strawberries, lychees, and grapes contained more than $180 \mathrm{mg} / 100 \mathrm{~g}$. The lowest concentration of polyphenol antioxidants were detected in melon and avocado. In the French diet, apples and strawberries were found to be the largest source of polyphenols among fruits and berries, while potato, onion, and lettuce salad were among vegetables. The total content of polyphenols consumed with fruits was three times as much as that received with vegetables. Calculation of the level of consumed polyphenols using the SECODIP program showed that apples and potatoes were the main sources of polyphenols in the French diet (constituting more than half of all consumed fruits and vegetables). The total polyphenol content in fresh fruits $(\mathrm{mg} / 100 \mathrm{~g})$ was as follows: strawberries (263.8), lychees (222.3), grapes (195.5), apricots (179.8), apples (179.1), dates (99.3), cherries (94.3), figs (92.5), pears (69.2), white nectarines (72.7), passion fruits (71.8), mango (68.1), yellow peaches (59.3), bananas (51.5), pineapples (47.2), lemons (45.0), yellow nectarines (44.2), grapefruits (43.5), oranges (31.0), clementines (30.6), limes (30.6), kiwis (28.1), watermelons (11.6), and melons (7.8).

The total polyphenol content in fresh vegetables (mg/100 g) was as follows: artichokes (core) (321.3), parsley (280.2), Brussels sprouts (257.1), shallots (104.1), broccoli (98.9), celery (84.7), onions (76.1), asparagus (14.5), eggplants (65.6), garlic (59.4), radishes (38.4), peas (36.7), purret (32.7), red peppers (26.8), cherry tomatoes (26.4), potatoes (23.1), zucchini (18.8), green peppers (18.2), chicory (14.7), tomatoes (13.7), dill (13.0), cauliflower (12.5), carrots (10.1), French green beans (10.0), and avocado (3.6).

The method used for determining of the total polyphenols content was inappropriate.

According to our data $[15,16]$ and data from other studies [17], the total content of polyphenols in lemons grapefruits, and oranges is higher than that found in banana; and these values for peppers, garlic, and onions are underestimated. These data should be reviewed as they do not reflect the reality and could mislead consumers.

\subsection{The level of polyphenol antioxidants consumption in Greece}

The modern Greek diet is significantly consistent with the Mediterranean diet, where foods of plant origin rich in antioxidants prevails [47-63]. The total content of polyphenols and their antioxidant capacity were assessed in 200 Greek food products. The effects of antioxidant consumption were investigated in 28,000 Greeks using the European Prospective Investigation into Cancer and Nutrition (EPIC) study.

The term 'Mediterranean diet' was introduced in 1971. People who used the Mediterranean diet were further found to have the lower frequency of chronic disorders including cardiovascular diseases, cancer, or Parkinson's and Alzheimer's 
disease [47]. Benefits of the Mediterranean diet is usually associated with either intensive consumption of the plant foods along with olive oil or lesser amount of the animal foods, in particular preferring fish over red meat, and moderate intake of wine at mealtimes. It was suggested that the positive effect of the Mediterranean diet is related to a high content of antioxidants [49]. High antioxidant capacity of serum and lower levels of oxidized LDLs were found in 3,000 healthy volunteers who followed the Mediterranean diet [53]. These findings were also confirmed by biochemical markers of antioxidants [55]. Over 28,000 volunteers have been interviewed about the frequency of consumption of 200 food products and 15 beverages. All food products were divided into 14 groups: potato, vegetables, root crops, fruits and nuts, dairy products, grain products, meat, fish, eggs, fats, sugar and sweets, non-alcoholic beverages, alcoholic beverages, sauces and seasonings.

The amount of antioxidants consumed by the volunteers has been determined. The average value of consumed flavonoids constituted approximately $92 \mathrm{mg}$ per day (including $7 \mathrm{mg}$ of flavones, $28 \mathrm{mg}$ of flavonols, $27 \mathrm{mg}$ of flavanones, $16 \mathrm{mg}$ of flavan-3-ols, $1 \mathrm{mg}$ of isoflavones, and $10 \mathrm{mg}$ of anthocyanidins). The primary sources of flavonoids were vegetables and wine. Flavonoids were detected in 100 traditional Greek food products. Intake of proanthocyanidins (polymeric flavan-3-ols) was estimated at approximately $87 \mathrm{mg}$ per day for Greeks, this value was previously reported to be $58 \mathrm{mg}$ and $83 \mathrm{mg}$ per day in the USA and Finland, respectively [42].

In the Greek diet, a person utilizes $4,660 \mathrm{mg}$ of beta-carotene, $214 \mathrm{mg}$ of vitamin $\mathrm{C}$, and $28 \mathrm{mg}$ of vitamin $\mathrm{E}$ per day-these values are significantly higher than those in other European countries [47]. For example, in Spain, these values are as follows: $1,679 \mathrm{mg}$ of beta-carotene, $137 \mathrm{mg}$ of vitamin $\mathrm{C}$, and $8.6 \mathrm{mg}$ of vitamin $\mathrm{E}$ [43]. The total consumption of polyphenols in the USA and France is 450 and $278.5 \mathrm{mg}$, respectively (relative to gallic acid). This is primarily contributed by consumption of oranges, apples, and potatoes in the USA49 and apples and potatoes in France [22]. The total consumption of polyphenols in Greece was estimated at 1,306 mg (relative to gallic acid), whereas this value was approximately $1,171 \mathrm{mg}$ per day in Spain (relative to gallic acid) [45]. The positive effect of the Mediterranean diet may be explained by a wide variety of antioxidants contained in it. This is confirmed by the fact that in certain cases, antioxidant therapy with one or more purified antioxidants was ineffective. In the Greek Mediterranean diet, the content of antioxidants significantly differs both quantitatively or qualitatively from that observed in diets used in other countries.

Taking daily olive oil and olives, an inhabitant of Greece receives $16 \mathrm{mg}$ of polyphenols, $12 \mathrm{mg}$ of alpha-tocopherol, $223 \mathrm{mg}$ of squalene, and $2 \mathrm{mg}$ of lignans [40].

Drawbacks of the study on determining the antioxidant content in the diet usually practiced in Greece were as follows [64]: 1) no consideration was paid to antioxidant transformation in food processing (including cooking); 2) no consideration was given to the different bioavailability of antioxidants; 3) transformation of antioxidants in food products depending on the climate and growing region was not accounted for; and 4) phenolic acids were not taken into account.

\subsection{The level of polyphenol antioxidants consumption in the USA}

The level of antioxidant intake by adults in the USA was estimated to be approximately $189.7 \mathrm{mg}$ per day with $83.5 \%$ being flavan-3-ols $[34,36,44]$. Percentage portions of other flavonoids included $7.6 \%$ of flavanones, $6.8 \%$ of flavonols, $1.6 \%$ of anthocyanidins, $0.8 \%$ of flavones, and $0.6 \%$ of isoflavones. The largest contribution was made by tea $(157 \mathrm{mg})$, citrus juices $(8 \mathrm{mg})$, wine $(4 \mathrm{mg})$, and citrus fruits (3 mg).

The level of flavonoids consumption defined in this study was substantially higher $(189.7 \mathrm{mg}$ per day) than that previously estimated in the USA (12-22 mg per day), and exceeded those noted in Denmark (23-46 mg per day) [28], Finland (24 mg per day) [42], the Netherlands 
(23-50 mg per day) [26], and Japan (63 mg per day) [32].

The level of consumption of 15 different flavonoids in Australia (except for isoflavones) was $128 \mathrm{mg}$ per day [39].

Later, the same authors [44] have determined the level of antioxidants received by adults from foods and dietary supplements, and the proportion of antioxidants in consumed fruits and vegetables in the USA [36]. The contents of proanthocyanidins [27], anthocyans [29], hydrophilic and lipophilic antioxidants [33] in foods were also determined in the USA.

Daily intake of vitamin $\mathrm{C}$ was reported to be about $206 \mathrm{mg}$ (46\% and 54\% from food and dietary supplements respectively), alphatocopherol about $20 \mathrm{mg}$ (36\% and 64\%), retinol about $223 \mathrm{mg}$ (the equivalent of carotenoids) (86\% and $14 \%$ ), selenium of $122 \mathrm{mg}(89 \%$ and $11 \%)$, and flavonoids of $210 \mathrm{mg}(98 \%$ and $2 \%)$.

\subsection{The level of polyphenol antioxidants consumption in Brazil}

The amount of flavonoids consumed with everyday food in Brazil has been determined [65]. It was calculated in different cities among people of different age and sex (over 900 persons). Consumed amounts of flavonoids ranged form 59.5 to $106.3 \mathrm{mg} /$ day. The content of some flavonoids in fruits and vegetables was assessed by HPLC: the concentration of quercetin was $46-56 \mathrm{mg} / 100 \mathrm{~g}$ in fresh white onions, 40$100 \mathrm{mg} / 100 \mathrm{~g}$ in red onions, $67-67.2 \mathrm{mg} / 100 \mathrm{~g}$ in red lettuce, $41-118 \mathrm{mg} / 100 \mathrm{~g}$ in arugula, 18-38 $\mathrm{mg} / 100 \mathrm{~g}$ in chicory, and $42 \mathrm{mg} / 100 \mathrm{~g}$ in tomatoes. In addition to quercetin, a small amount of luteolin was discovered in these vegetables.

The high content of all flavonoids (hesperidin, naringenin, and quercetin) were shown in oranges: $125-170 \mathrm{mg} / 100 \mathrm{~g}$ in the orange peel, $34-44 \mathrm{mg} / 100 \mathrm{~g}$ in the orange flesh. Therefore, the orange peel is richer in flavonoid antioxidants - 3 times as much as the orange flesh.

Quercetin, epicatechin, catechin, and phlorizin have been detected in apples (Gala, Fuji, Golden Delicious). Their total content ranged from 14 to $36 \mathrm{mg} / 100 \mathrm{~g}$.
The average intake of flavonoids by the Brazilian population aged 17-88 was reported to be $79 \mathrm{mg}$ per day for women and $86 \mathrm{mg}$ per day for men.

\section{The Mediterranean diet}

Many scientific papers devoted to the Mediterranean diet have been published in recent decades including books and reviews [47-63]. Primarily these refer to diets of such countries as Greece, Italy, France, and Spain. In these countries, the frequency of cardiovascular and gastrointestinal diseases, and cancer is lower compared to Northern and Central Europe. The United Nations is planning to include the Mediterranean diet in the UNESCO World Heritage classification. It is considered that the Mediterranean diet implies not only a specific set of food products but also the culture and customs of consumption. The term 'Mediterranean diet' suggests that all inhabitants of the Mediterranean region, including African countries, have the same diet, but this is not true [62]. Mediterranean countries have different diets, religions, and cultures. Their diets vary by the amount and type of fats, olive oil, meat, wine, milk, cheese, fruits, and vegetables consumed. Therefore, it would be more appropriate to refer to the diet of the Mediterranean part of Europe as a 'Mediterranean diet'. The Greek diet is the most prominent representative of this diet. The traditional Greek diet includes vegetables, fruits (including wild plants), nuts and grains, olive oil, olives, cheese, fish, wine, and meat. Grains are used mainly as fermented bread. In Greece, the consumption of milk and meat is lower, but intake of cheese, fish, and wine is higher compared to other Mediterranean countries. Analysis of the diet on the island of Crete shows that this diet contains all essential protective substances such as selenium and glutathione, has a balanced ratio of omega- 6 and omega- 3 fatty acids, and is rich in fiber and antioxidants.

Cardioprotective and anticancer properties of the Mediterranean diet are thought to be related to high levels of antioxidants. However, no studies supporting this hypothesis have been performed until recently. In the last few years, 
some articles have been published on the role of antioxidants in the Mediterranean diet [49], the relationship between oxidative stress and the Mediterranean diet [51], etc. Markers of oxidative stress are separately studied in people who are embracing the Mediterranean diet, in particular markers of DNA [63] and low-density lipoprotein oxidation [53]. The causal association between the Mediterranean diet and the emergence of oxidative stress markers, in particular a reduced ratio of glutathione to oxidized glutathione (GSH/GSSG), was explored in 138 monozygotic and dizygotic twins [54]. These studies have demonstrated that GSH/GSSG ratio increased during the use of the Mediterranean diet and that it is not related to genetic factors. Suppression of oxidative stress when using the Mediterranean diet results in reduced risk of cardiovascular diseases [59]. In this case, the Mediterranean diet used was as described in the reference [57]. It consists of seven necessary and useful components: grains, vegetables, fruits, nuts, beans, fish, large amounts of olive oil, which has the optimal ratio of monounsaturated to saturated fatty acids, and a moderate amount of wine. Meat and dairy products were two undesirable components of this diet.

The effects of the Mediterranean diet on the content of other oxidative stress markers in human biological fluids were investigated in several publications [53-55].

Use of olive oil is of particular importance in the Mediterranean diet. Previously, it was argued that a high intake of olive oil protects DNA molecules from oxidative damage reducing the incidence of various cancers. Experts from the Institutions of Nutrition, Medicine, and Pharmaceutics from North, Central and Southern Europe (Germany, Denmark, Finland, Italy, and Spain) have explored the effects of olive oil consumption on DNA and RNA oxidative stress markers [63]. A total of 182 healthy men were included in the experimental monitoring of oxidation markers (8-oxo-guanidine, 8-oxoguanosine and 8-oxo-deoxyguanosine) in urine before and after ingestion of $25 \mathrm{ml}$ of olive oil with low, medium and high levels of phenolic compounds. Concentrations of 8-oxo-guanosine
(RNA oxidation marker) and 8-oxodeoxyguanosine (DNA oxidation marker) in the urine of men from Northern Europe were demonstrated to be higher than those in men from Central and Southern Europe. A decrease of 8hydroxylated forms of guanine, guanosine, and deoxyguanosine and their unoxidized forms in urine after taking of olive oil for two weeks does not depend on the levels of phenolic compounds in oil. The content of 8-oxo-deoxyguanosine after consumption of olive oil decreased by $13 \%$. These findings confirm the hypothesis that olive oil reduces the oxidation of DNA, and therefore attenuates the risk of neoplastic malignancies. However, this effect is not related to the amount of polyphenols in olive oil. Imbalance between the human antioxidant system and formation of reactive oxygen and nitrogen species (RONSs) including free radicals, leads to oxidative stress. The DNA molecule may be one of the targets for free radicals. Accumulation of mutations following DNA oxidation promotes carcinogenesis [66-68]. Hydroxylation of guanine at position 8 yielding 8 -oxo-deoxyguanosine is the most common process $[68,69]$. These markers are excreted in urine, and could be used to assess the level of oxidative stress [70]. Other derivatives of guanine such as 8-oxo-guanine and 8-oxo-guanosine may also serve as biomarkers of DNA oxidation. These markers should predict the emergence of dangerous diseases. Preferably, the sampling of markers should be non-invasive (urine, saliva, sputum sampling) or slightly invasive (blood sampling).

The frequency of neoplastic malignances including breast, colon, ovarian, endometrial, and prostate cancer in Mediterranean countries is lower than that in Northern Europe [63]. Causal relation between intensive consumption of olive oil and reduced risk of breast [63], colorectal [71], oral cavity, glandular [72], and esophageal cancer [55] has been established.

Olive oil is rich in monounsaturated fatty acids, primarily oleic acid [73]. In addition, olive oil contains a large variety of phenolic compounds including antioxidants, in particular oleuropein and its derivative, hydroxytyrosol [55]. Olive oil contains predominantly oleuropein $(65 \%)$, ligstrosid aglycone (18\%), hydroxytyrosol 
(11\%), tyrosol (4\%), and flavonoids (1\%) [55]. Different varieties of olive oils contain different concentrations of polyphenol antioxidants, but are almost the same in the content of fatty acids, $\alpha$-tocopherol, squalene, and $\beta$-sitosterol.

\section{Antioxidants and sports}

Intense physical exercise provokes an increase of free radicals and other reactive nitrogen species in working muscles. Studies conducted in recent years clearly show that reactive oxygen species are responsible for the oxidation of proteins induced by intense physical exercises and make a major contribution to resulting muscle fatigue [74-110]. The human body has an endogenous system which protects against oxidative damage during exercise. However, during overly intensive physical activities and excessive training, the endogenous system does not manage to cope with the stress, and an athlete does not get sufficient restoration before important competition events. In this case, the use of dietary antioxidants is crucial.

A positive effect of exogenous dietary antioxidants has been reported in numerous studies (see Table 5) [74-110].

Table 5. The reported positive effect of dietary antioxidants in different studies.

\begin{tabular}{|l|l|c|}
\hline No. & \multicolumn{1}{|c|}{ Studies Conducted } & References \\
\hline 1 & Free radicals and antioxidant strategies in sports. & {$[111]$} \\
\hline 2 & Oxidative stress during sports training. & {$[79,89]$} \\
\hline 3 & Prospects of antioxidant therapy. & {$[76-81]$} \\
\hline 4 & Oxidants and antioxidants during physical exercises. & {$[78,82]$} \\
\hline 5 & Oxidative stress induced by exercising. & {$[109]$} \\
\hline 6 & Oxidants, antioxidant foods, and athletes. & {$[109]$} \\
\hline 7 & Free radicals, exercises, and antioxidant dietary supplements. & {$[87]$} \\
\hline 8 & Free radical tissue damage: protective role of antioxidants. & {$[111]$} \\
\hline 9 & Protective role of antioxidants in muscle damage. & {$[111]$} \\
\hline 10 & Effect of antioxidants on the peak of athletes' fitness. & \multicolumn{1}{|c|}{} \\
\hline
\end{tabular}

The antioxidant status of athletes should be determined during training sessions in order to prevent its abnormalities. The level of antioxidant status could be maintained by a reasonable antioxidant therapy. Only under these conditions can an athlete reach the peak of fitness and maintain it at the proper level over an extended period of time (see Table 6).

\section{Oxidative stress diagnostics. Markers of oxidative stress.}

In recent years, great attention has been given to diagnostics of oxidative stress due to the fact that oxidative stress, i.e., excessive levels of free radicals in the human body caused by adverse environmental conditions, stresses, irradiation, contaminated food and smoking, may lead to many diseases [112-136]. In addition, oxidative stress may result from intake of medication with pro-oxidant properties (such as tetracyclines, aminazine, rubomycin, iron- and coppercontaining medicinal products, etc.), and from a number of treatments (such as oxygen therapy, hyperbaric oxygen therapy, ultraviolet or laser irradiation).

Long-term oxidative stress inevitably leads to the emergence of dangerous socially significant 
diseases (such cardiovascular diseases, cancer, diabetes, and others - over 100 diseases in total) as well as to premature aging. Therefore, oxidative stress is a primary factor triggering the development of many dangerous diseases, including those with fatal outcomes.

Table 6. Antioxidants and Sports (Review of Publications from 1993-2007).

\begin{tabular}{|c|c|c|}
\hline No. & Publications & References \\
\hline 1 & $\begin{array}{l}\text { Determination of oxidative } \\
\text { stress markers in athletes. }\end{array}$ & [83] \\
\hline 2 & $\begin{array}{l}\text { Antioxidants against muscle } \\
\text { damage during physical } \\
\text { exercises. }\end{array}$ & \\
\hline & $\begin{array}{l}\text { 2.1. Endogenous antioxidants: } \\
\text { - Glutathione restored; } \\
\text { - Ubiquinol; } \\
\text { - Cysteine; N-acetylcysteine; } \\
\text { - Carnitine, choline; } \\
\text { - Lipoic acid. } \\
\text { 2.2. Exogenous antioxidants: } \\
\text { - Vitamin E; } \\
\text { - Vitamin C; } \\
\text { - Carotenoids; } \\
\text { - Flavonoids; } \\
\text { - Selenium compounds; } \\
\text { - N-acetylcysteine. }\end{array}$ & $\begin{array}{c}{[80,81,86]} \\
{[111]} \\
{[111]} \\
{[111]} \\
{[111]} \\
{[106]}\end{array}$ \\
\hline 4 & Antioxidant therapy. & {$[1,2]$} \\
\hline
\end{tabular}

The human body has a natural three-tier antioxidant protection system fighting against free radicals. Certain amounts of free radicals are essential for the human body as they participate in a variety of biochemical processes and maintain immune status. However, excessive levels of free radicals inevitably result in pathological changes in the human body. This condition is called oxidative stress.
The vast majority of known theories of aging are based on the theory of oxidative stress development. Numerous scientific publications have confirmed that oxidative stress underlies the development of the most dangerous and socially significant diseases, such as cardiovascular diseases, cancer, diabetes mellitus, impairment of cerebral circulation, inflammatory, rheumatic, neurodegenerative disorders (Parkinson's disease, Alzheimer's disease), etc [112-117].

It is therefore extremely important to diagnose the onset of oxidative stress before it leads to severe changes in the body. There are quick tests, such as the amperometric method, for diagnosing the presence of oxidative stress. They are based on evaluation of the antioxidant status, i.e., measuring the total content of antioxidants in the body.

There are also more reliable methods of oxidative stress detection. Some of them rely on the identification of special markers at concentrations ranging from $10-12$ to $10-9 \mathrm{~g} / \mathrm{cm} 3$ which appearance in biological fluids of the body indicates an ongoing oxidative process. Other approaches are used to detect endogenous antioxidants. These include glutathione (GSH), cysteine, uric acid, and ubiquinol-all of which are molecules and compounds that can exist in a reduced form (which makes them antioxidants) or in an oxidized form.

When the content of reactive oxygen species and free radicals in the body fluids and cells becomes excessive, the human antioxidant system is unable to neutralize them. As a consequence, they start oxidizing essential molecules, such as DNA, proteins, lipids, and carbohydrates. Oxidation of these molecules yields the oxidation markers.

Many modifications of DNA and RNA molecules induced by oxidative stress lead to cell lesions, sometimes possessing a mutagenic nature. This process leads to the development of cancer and premature aging. Currently, the European Committee was established in order to standardize different types of DNA impairments. In particular, the level of 8-hydroxy-2'deoxyguanosine in cellular DNA is normalized at the limit of 0.5-5 impairment per 106 guanosine bases [118]. 
Modified nucleosides are determined by several methods including gas chromatographymass spectrometry (GC-MS), HPLC-MS/MS, HPLC with amperometric detection, as well as immune methods and electrophoresis [119]. Nucleosides are compounds where one of the bases of a nucleic acid is bridged with a pentose. These compounds are called either ribonucleosides or deoxyribonucleosides depending on the type of sugar attached. The most important nucleosides are formed on the basis of adenosine, guanosine, cytidine, and uracil. Normal nucleosides are reutilized in the body; however, modified nucleosides are not able to be inserted into RNA and DNA during their synthesis. They are excreted in urine along with a small portion of normal nucleosides. Therefore, the levels of modified nucleosides in urine provide a criterion to track DNA and RNA impairments. When free radicals affect these molecules during oxidative stress development, oxidized forms of nucleosides and their precursors become quantifiable in urine. The most informative forms would be 8-hydroxy-2'deoxyguanosine, 5-hydroxy-2'-deoxycytidine, 5hydroxy-2'-deoxyuridine.

Oxidation of DNA and RNA molecules frequently leads to the development of cancers and premature aging. Currently, many papers have been published on the detection of 8-hydroxy-2'-deoxyguanosine in urine and serum in patients and healthy volunteers [120-123]. Modified nucleosides are isolated from urine onto special cartridges or determined directly in urine using appropriate preparation and centrifuging. Modified nucleosides may be isolated by applying Affi-Cel cartridges. These modified nucleosides are detected by a UV detector. The oxidized forms are detected by an amperometric detector.

In recent years, modified nucleosides including 8-hydroxy-2'-deoxyguanosine have successively been detected without isolation on the Affi-Cel cartridge. In order to do this, a patient's urine is centrifuged and injected into a chromatograph.

Predominantly, membranous unsaturated fatty acids are subjected to the damaging effects of free radicals. Markers of lipid oxidation are represented by aldehydes, dialdehydes, methylglyoxal, and derivatives of hexenal, nonenal, or isoprostane.

Malondialdehyde (MDA) is commonly used as a marker, and considered the most informative. MDA is formed upon the breaking of polyunsaturated fatty acid molecules during lipid peroxidation induced by free radicals. The increased serum concentration of MDA serves as a marker of endogenous intoxication and reflects the degree of oxidative stress [124-127]. MDA forms a Schiff base with protein amino groups resulting in the formation of insoluble lipidprotein complexes (aging pigment).

MDA is determined in samples of many biological fluids: serum, plasma, urine, exhaled breath condensate. Serum samples are most commonly used for detecting MDA. Such an approach is the most reliable, and sample preparation is easier and less expensive. The serum concentration of MDA in healthy subjects (within the normal range) is less than $1 \mu \mathrm{mol} / 1$.

The HPLC method with photometric detection in the visible region (with the wavelength of approximately $\lambda=532 \mathrm{~nm}$ ) provides the most reliable results. The reaction with thiobarbituric acid is used to detect MDA. Reaction of MDA with thiobarbituric acid yields a colored trimethine complex (with absorbance at $532-535 \mathrm{~nm}$ ). The derivatives of this reaction can be fluorimetrically visualized, the results of MDA determination obtained by different methods have been compared in one publication. The results of an examination of more than 200 healthy subjects (107 men and 106 women), in which MDA was determined by HPLC with photometric detection at $532 \mathrm{~nm}$, are provided in the referenced article [127]. The concentrations of MDA in samples were found to range from 0.36 to $1.24 \mu \mathrm{mol} / \mathrm{l}$. According to the results of analysis, MDA concentration was shown to be almost independent of gender and age of the examined subjects. Increased MDA plasma concentrations have been observed in smokers and in people who consume alcohol.

Tyrosine or $\alpha$-amino- $\beta$-(n-oxyphenyl)propyl acid is nonessential amino acid with an aromatic ring and hydroxyl group in the para position, hence tyrosine is an antioxidant. In the human 
body the only existing form is L-tyrosine, which plays a part in proteins and enzymes. Tyrosine is an important amino acid being a precursor of such biologically active compounds as epinephrine, norepinephrine, dopamine, etc. When exposed to free radicals, the free tyrosine or tyrosine contained in the proteins is oxidized. This process generates tyrosine derivatives which are able to mark protein oxidation (3chlorotyrosine, 3-nitrotyrosine, 3,5dichlorotyrosine, dityrosine, etc.). The appearance of these markers in biological fluids occurs in atherosclerosis, Parkinson's and Alzheimer's diseases and other disorders. Dityrosine is a specific marker of oxidative stress in the brain. Oxidized forms of tyrosine are easily determined utilizing amperometric detection [128-129].

Some endogenous antioxidants are always present in human bodily fluids; among them are glutathione (GSH), cysteine, uric acid, and ubiquinol. Molecules of these compounds exist either in a reduced form (antioxidants) or in an oxidized form (see Table 7).

Table 7. A List of the Reduced and Oxidized Forms of Oxidative Stress Markers Used for the Assessment of the Oxidative Stress

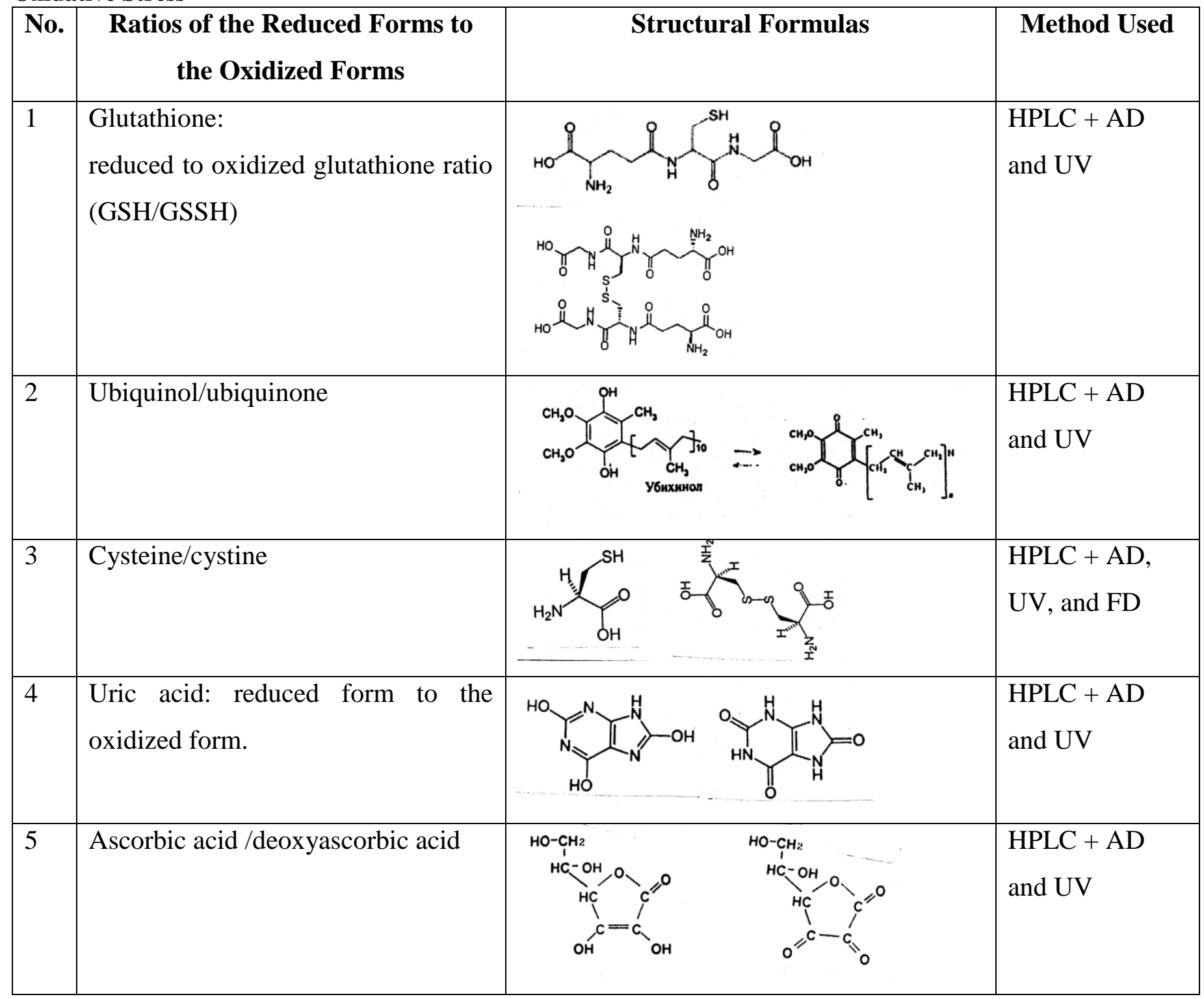

Note. HPLC — -high performance liquid chromatography; AD—amperometric detection; UV—ultraviolet detection; FD-fluorometric detection. 
These endogenous antioxidants are oxidized upon encountering free radicals or an active form of oxygen or nitrogen, but after a certain period of time they are recovered by special enzymes. This mechanism in the biological fluids of healthy people helps maintaining a balance between oxidants and antioxidants in the body.

The chromatographic method is used to determine the ratio between reduced and oxidized forms of glutathione, uric acid, cystine to cysteine, ubiquinol to ubiquinone [130-137]. An exogenous antioxidant-ascorbic acid-also exists in two forms. The ratio of nitrite to nitrate in the saliva is also associated with the redox ratio. These endogenous antioxidants are determined by chromatographic methods [130137].

The introduction of the HPLC method for the determination of oxidative stress markers in the standard biochemical laboratories of hospitals and diagnostic centers will allow for prompt diagnostics of oxidative stress at its very onset. Timely prescribed antioxidant therapy will prevent the development of diseases. Such preventive screening will significantly reduce healthcare costs.

\section{Antioxidant therapy}

Antioxidant therapy is widely used in current medical practice. A large group of antioxidant drugs has already been developed.

In Russia, the following drugs are most commonly used: mexidol, mexicar, hypoxen, kudesan, carnitine, noben, theagal, and polyoxidonium [16].

Some of these drugs are synthetic whereas others are of plant origin. Dietary supplements are also used to increase the antioxidant status of people. However, consumption of foods with a certain content of antioxidants is the most important antioxidant therapy; a special functional diet can be developed for a person. In practice, it means following the Hippocratic precept, "Let your food be your medicine, and your medicine be your food."

The number of publications devoted to the antioxidant therapy for various diseases has tremendously increased over the last few years.
The list of such publications is provided in Table 8.

\section{Discussion}

At the conclusion of this review, we can say that a rather large data set on antioxidant content in foods and beverages has already been created in several countries. The measurement and research are actively ongoing - antioxidant activity is currently being determined for some rare berries, fruits, spices, and medicinal plants in South America, Africa, and Asia. A large number of studies have been undertaken to determine the antioxidant activity in plants used in traditional Chinese medicine.

Existing data on the content of anthocyanins, proanthocyanidins, and lignans in foods and their impact on human health are insufficient. In one study, it was shown that the content of proanthocyanidins in some foods is higher than the content of other polyphenols [27]. The higher content was found, for example, in the following products $(\mathrm{mg} / 100 \mathrm{~g})$ : grape seeds - 3,532.3; cranberries - 418.8; (wild) blueberries - 331.9; blueberries (cultivated) - 179.8; blackcurrants 147.8; strawberries - 145.0; black plums - 237.9; baking chocolate $-1,635.9$; red wine -313.5 ; grape juice - 524.7; sorghum (bran) - 3,965.4; raw (pinto) beans -796.3 ; red beans - 456.6; kidney beans - 563.8; nuts (pecans) - 494.1; pistachios - 237.3, etc.

Quite a lot of information is now available on the consumption rates of antioxidants in various countries.

Unfortunately, many methods used for the determination of antioxidant activity correlate poorly with each other-much more work is needed to assure the uniformity of measurements $[16,30]$. Too little research has been conducted on the mechanism of metabolism of polyphenol antioxidants in the intestinal tract, their digestibility, absorption, and pharmacokinetics.

Some data provides evidence that flavonoids, and especially mixtures thereof, are not only the most powerful antioxidants but also induce other biological processes.

A few recent studies investigated the possible synergistic action of some polyphenol 
combinations. This possibility is important to understand in order to prevent adverse effect of excessive antioxidant action which could be triggered by large amounts of antioxidants. Research on protection against radiation by antioxidants has been resumed - one publication even argues that in future missions to Mars it would be impossible to protect astronauts from radiation without the use of antioxidants (as it is difficult to remain completely isolated from radiation in space).

Table 8. Antioxidant Therapy for Various Diseases.

\begin{tabular}{|c|c|c|}
\hline No. & Name of Disease & Reference \\
\hline 1 & Cardiovascular diseases & [138-143] \\
\hline 2 & Atherosclerosis & [144] \\
\hline 3 & Ischemic stroke & [145] \\
\hline 4 & Extensive myocardial infarction & [146] \\
\hline 5 & Multiple sclerosis & {$[147,148]$} \\
\hline 6 & Systemic sclerosis & [149] \\
\hline 7 & Cancers & [150-152] \\
\hline 8 & Prostate cancer & [153] \\
\hline 9 & Melanoma & [154] \\
\hline 10 & Diabetes & [155-158] \\
\hline 11 & Diabetic neuropathy & [159] \\
\hline 12 & Diabetic nephropathy & [160] \\
\hline 13 & Neurodegenerative diseases & [161-164] \\
\hline 14 & Alzheimer's disease & [165-167] \\
\hline 15 & Parkinson's disease & [168] \\
\hline 16 & Epilepsy & [169] \\
\hline 17 & Sepsis & [170-174] \\
\hline 18 & Rheumatoid arthritis & [175] \\
\hline 19 & Renal failure & [176-178] \\
\hline 20 & Chronic liver disease & [179] \\
\hline 21 & Chronic hepatitis C & [180] \\
\hline 22 & Asthma & [181-183] \\
\hline 23 & Respiratory diseases & [184] \\
\hline 24 & Inflammatory bowel disease & [185] \\
\hline 25 & Burn injuries & [186] \\
\hline
\end{tabular}




\begin{tabular}{|l|l|c|}
\hline \multicolumn{1}{|c|}{ No. } & \multicolumn{1}{|c|}{ Name of Disease } & Reference \\
\hline 26 & Female infertility & {$[187]$} \\
\hline 27 & Male infertility & {$[188]$} \\
\hline 28 & AIDS & {$[189,190]$} \\
\hline 29 & Depression & {$[191]$} \\
\hline 30 & Migraine & {$[192]$} \\
\hline 31 & Oxidative stress & {$[193]$} \\
\hline 32 & Uremia & {$[194]$} \\
\hline 33 & Neuroprotection in newborns & {$[195]$} \\
\hline 34 & Shock and inflammations & {$[196]$} \\
\hline 35 & Pancreatitis & {$[197,198]$} \\
\hline
\end{tabular}

\section{Acknowledgments}

The authors would like to thank John Hunter and Rebecca Wang for their excellent technical assistance.

\section{References}

1. Matkovics, A., New strategies of antioxidant terapia. Orv. Hetil. 2006, 147, 747-752.

2. Shanin, Y.N.; Shanin, V.Y.; Zinoviev, E.V., Antioxidant therapy in clinical practice. Albee Publishing House: Moscow, 2009; p 128

3. Møller, P.; Loft, S., Dietary antioxidants and beneficial effect on oxidatively damaged DNA. Free Radic Biol Med. 2006, 41,388-415.

DOI:10.1016/j.freeradbiomed.2006.04.001

4. Firuzi, O.; Miri, R.; Tavakkoli, M.; Saso, L., Antioxidant therapy: Current status and future prospects. Current Medicinal Chemistry 2011, 18, 3871. DOI:10.2174/092986711803414368

5. Tomás-Barberán, F.A.; Lacueva, C.A., Polyphenols and health: Current state and progress. J. Agric. Food Chem. 2012, 60, 8773-8775. DOI: $10.1021 / \mathrm{jf300671j}$
6. Wootton-Beard, P.C.; Ryan, L., Improving public health?: The role of antioxidant-rich fruit and vegetable beverages. Food Research International 2011, 44, 31353148. DOI:10.1016/j.foodres.2011.09.015

7. Iannitti, T.; Palmieri, B., Antioxidant therapy effectiveness: An up to date. Eur Rev Med Pharmacol Sci 2009, 13, 245-278.

8. Iannitti, T.; Palmieri, B., Antioxidant therapy and its effectiveness in oxidative stress-mediated disorders, in oxidative stress in vertebrates and invertebrates: Molecular aspects of cell signaling. John Wiley \& Sons, Inc.: Hoboken, 2011; p 209234. DOI: 10.1002/9781118148143.ch15

9. Currocrea, S.; Riley, D.P.; Caputi, A.P., Salvemini. Antioxidant therapy: A new pharmacological approach in shock, inflammation and ischemia/reperfusion injury. Pharmacol. Rev. 2001, 53, 135-159.

10. Scalbert, A.; Andres-Lacueva, C.; Arita, M.; Kroon, P.; Manach, C.; Urpi-Sarda, M.; Wishart, D., Databases on food phytochemicals and their health promoting effects. J. Agric. Food Chem. 2011, 59, 4331-4348. DOI: 10.1021/jf200591d

11. Willcox, B.J.; Willcox, D.C.; Suzuki, M., Why japanese don't get old. Secrets from the land of the rising sun. Ritol Classic: Moscow, 2010; p 544. 
12. Campbell, T.C.; Campbell, T.M., The china study. The most comprehensive srudy of nutrition ever conducted and startling implications for diet, weigt loss and longterm health. . Dallas, Texas, 2006.

13. Trukhanov, A.I., Anti-age medicine: Science to stay young. Asvomed: 2012.

14. Carlsen, M.H.; Halvorsen, B.L.; Holte, K.; Bøhn, S.K.; Dragland, S.; Sampson, L.; Willey, C.; Senoo, H.; Umezono, Y.; Sanada, C., et al., The total antioxidant content of more than 3100 foods, beverages, spices, herbs and supplements used worldwide. Nutr J. 2010, 9, 1-11. DOI: 10.1186/1475-2891-9-3

15. Yashin, Y.I.; Nemzer, B.V.; Ryzhnev, V.Y.; Yashin, A.Y.; Chernousova, N.I.; Fedina, P.A., Creation of a databank for content of antioxidants in food products by an amperometric method. Molecules 2010, 15, 7450-7466.

DOI:10.3390/molecules 15107450

16. Yashin, Y.I.; Ryzhnev, V.Y.; Yashin, A.Y.; Chernousova, N.I., Natural antioxidants. Content in foods and their effects on health and aging. TransLit: Moscow, 2009.

17. USDA database for the flavonoid content of selected foods. 2007/01/31 ed.; 2007.

17a. USDA database for the proanthocyanidin content of selected foods. 2004. [cited 2009 Oct 10]. Available from: http://www.nal.usda.gov/fnic/foodcomp/Data/PA /PA.pdf.

18. Pérez-Jiménez, J.; Neveu, V.; Vos, F.; Scalbert, A., Systematic analysis of the content of 502 polyphenols in 452 foods and beverages: An application of the phenol-explorer database. J. Agric. Food Chem. 2010, 58, 4959-4969. DOI: $\underline{10.1021 / \mathrm{j} 100128 \mathrm{~b}}$

19. Gry, J.; Black, L.; Eriksen, F.D.; Pilegaard, K.; Plumb, J.; Rhodes, M.; Sheehan, D.; Kiely, M.; Kroon, P., Eurofir-basis - a combined composition and biological activity database for bioactive compounds in plant-based foods. . Trends Food Sci. Technol. 2007, 18, 434-444. DOI: 10.1016/j.tifs.2007.05.008

20. Halvorsen, B.L.; Carlsen, M.H.; Phillips, K.M.; Bohn, S.K.; Holte, K.; Jacobs, D.R.;
Blomhoff, R., Content of redox-active compounds (ie, antioxidants) in foods consumed in the united states. Am. J. Clin. Nutr. 2006, 84, 95-135.

21. Gost, R., Foodstuffs. Determination of the content of water-soluble antioxidants by amperometric method in vegetables, fruits, products of their processing, alcoholic and soft drinks. Izd. Standartov: Moscow, 2010.

22. Brat, P.; George, S.; Bellamy, A.; Du Chaffaut, L.; Mennen, L.; Arnault, N.; Amiot, M.J., Daily polyphenol intake in france from fruit and vegetables. J. Nutr. 2006, 136, 2368-2373.

23. Wu, X.L.; Beecher, G.R.; Holden, J.M.; Haytowitz, D.B.; Gebhardt, S.E.; Prior, R.L., Lipophilic and hydrophilic antioxidant capacities of common foods in the united states. J. Agric. Food Chem. 2004, 52, 4026-4037. DOI: 10.1021/jf049696w

24. Park, M.K.; Song, Y.J.; Joung, H.; Li, S.J.; Paik, Y., Establishment of an isoflavone database for usual korean foods arid evaluation of isoflavone intake among korean children. Asia Pac. J. Clin. Nutr. 2007, 16, 129-139.

25. Radtke, J.; Linseisen, J.; Wolfram, G., Phenolic acid intake of adults in a bavarian subgroup of the national food consumption survey. Ernaehrungswiss. Z 1998, 37, 190197.

26. Arts, I.C.W.; van de Putte, B.; Hollman, P.C.H., Catechin contents of foods commonly consumed in the Netherlands. 2. Tea, wine, fruit juices, and chocolate milk. J. Agric. Food Chem. 2000, 48, 1752-1757. DOI: $10.1021 / \mathrm{j} f 000026 \% 2 \mathrm{~B}$

27. Gu, L.; Kelm, M.A.; Hammerstone, J.F.; Beecher, G.R.; Hollman, P.C.H.; Haytowitz, D.B.; Gebhardt, S.E.; Prior, R.L., Concentrations of proanthocyanidins in common foods and estimations of normal consumption. J. Nutr. 2004, 134, 613-617.

28. Milder, I.E.; Arts, I.C.; van de Putte, B.; Venema, D.P.; Hollman, P.C., Lignan contents of Dutch plant foods: A database including lariciresinol, pinoresinol, secoisolariciresinol and matairesinol. . $\mathrm{Br}$. 
J. Nutr. 2005, 93, 393-402. DOI: 10.1079/BJN20051371

29. Wu, X.L.; Beecher, G.R.; Holden, J.M.; Haytowitz， D.B.; Gebhardt, S.E.; Prior, R.L., Concentrations of anthocyanins in common foods in the United States and estimation of normal consumption. . $J$. Agric. Food Chem. 2006, 54, 4069-4075. DOI: 10.1021/jf0603001

30. Pellegrini, N.; Serafini, M.; Salvatore, S.; Del Rio, D.; Bianchi, M.; Brighenti, F., Total antioxidant capacity of spices, dried fruits, nuts, pulses, cereals and sweets consumed in Italy assessed by three different in vitro assays. Mol. Nutr. Food Res. 2006, 50, 1030-1038. DOI: 10.1002/mnfr.200600067

31. Hertog, M.G.L.; Hollman, P.C.H.; Katan, M.B.; Kromhout, D., Intake of potentially anticarcinogenic flavonoids and their determinants in adults in the Netherlands. Nutr Cancer. 1993, 20, 21-29. DOI: 10.1080/01635589309514267

32. Arai, Y.; Watanabe, S.; Kimira, M.; Shimoi, K.; Mochizuki, R.; Kinae, N., Dietary intakes of flavonols, flavones and isoflavones by Japanese women and the inverse correlation between quercetin intake and plasma ldl cholesterol concentration. $J$ Nutr. 2000, 130, 2243-2250.

33. Lyons-Wall, P.; Autenzio, P.; Lee, E.; Moss, R.; Gie, S.; Samman, S., Catechins are the major source of flavonoids in a group of Australian women. . Asia Pac J Clin Nutr. 2004, 13, S72.

34. Chun, O.K.; J., C.S.; Song, W.O., Estimated dietary flavonoid intake and major food sources of U.S. Adults. . J Nutr. 2007, 137, 1244-1252.

35. Kita, J.; Tada, J.; Ito, M.; Shirakawa, M.; Murashima, M.; Zhuo, X.-G.; Watanabe, S., Intake of phytochemicals among Japanese, calculated by a new fff database. . Biofactors 2004, 22, 259-263.

36. Chun, O.K.; Kim, D.-O.; Smith, N.L.; Schroeder, D.; Han, J.T.; Lee, C.Y., Daily consumption of phenolics and total antioxidant capacity from fruit and vegetables in the American diet. $J$ Sci Food Agric. 2005, 85, 1715-1724. DOI: 10.1002/jsfa.2176

37. Sampson, L.; Rimm, E.; Hollman, P.C.; de Vries, J.H.; Katan, M.B., Flavonol and flavone intakes in us health professionals. . $J$ Am Diet Assoc. 2002, 102, 1414-1420. DOI: 10.1016/S0002-8223(02)90314-7

38. Garcia-Closas, R.; Berenguer, A.; Jose, T.M.; Jose, S.M.; Quiros, J.R.; Navarro, C.; Arnaud, R.; Dorronsoro, M.; Dolores, C.M., Dietary sources of vitamin c, vitamin e and specific carotenoids in Spain. Br J Nutr. 2004, 91, 1005-1011. DOI: 10.1079/BJN20041130

39. Johannot, L.; Somerset, S.M., Age-related variations in flavonoid intake and sources in the Australian population. Public Health Nutr. 2006, 9, 1045-1054. DOI: 10.1017/PHN2006971

40. Dilis, V.; Vasilopoulou, E.; Trichopoulou, A., The flavone, flavonol and flavan-3-ol content of the Greek traditional diet. Food Chem. 2007, 105, 812-821. DOI: 10.1016/j.foodchem.2007.01.069

41. Vasilopoulou, E.; Georga, K.; Joergensen, M.B.; Naska, A.; Trichopoulou, A., The antioxidant properties of Greek foods and the flavonoid content of the mediterranean menu. . Curr Med Chem Immunol Endocr Metab Agents. 2005, 5, 33-45.

42. Ovaskainen, M.L.; Toronen, R.; Koponen, J.M.; Sinkko, H.; Hellstrom, H.; Reinivuo, H.; Mattila, P., Dietary intake and major food sources of polyphenols in Finnish adults. J nutr. 2008, 138, 562-566.

43. Agudo, A.; Cabrera, L.; Amiano, P.; Ardanaz, E.; Barricarte, A.; Berenguer, T.; Chirlaque, M.; Dorronsoro, M.; Jakszyn, P.; Larrañaga, N., et al., Fruit and vegetable intakes, dietary antioxidant nutrients, and total mortality in Spanish adults: Findings from the Spanish cohort of the european prospective investigation into cancer and nutrition (epic-spain). . Am J Clin Nutr. 2007, 85, 1634-1642.

44. Chun, O.K.; Floegel, A.; Chung, S.J.; Chung, C.E.; Song, W.O.; Sung, I.K., Estimation of antioxidant intakes from diet 
and supplements in us adults. . $J$ Nutr. 2010, $140, \quad 317-324 . \quad$ DOI: 10.3945/jn.109.114413

45. Saura-Calixto, F.; Goni, I., Antioxidant capacity of the Spanish mediterranean diet. Food Chem. 2006, 94, 442-447. DOI: 10.1016/j.foodchem.2004.11.033

46. George, S.; Brat, P.; Alter, M.J., Rapid determination of polyphenols and vitamin $\mathrm{c}$ in plant derived products. J. Agric. Food Chem. 2005, 53, 1370-1373. DOI: 10.1021/jf048396b

47. Trichopoulou, A.; Costacou, T.; Bamia, C.; Trichopoulos, D., Adherence to a mediterranean diet and survival in a Greek population. N Engl J Med 2003, 348, 25992608.

48. Mitrou, P.N.; Kipnis, V.; Thiebaut, A.C.; Reedy, J.; Subar, A.F.; Wirfält, E.; Flood, A.; Mouw, T.; Hollenbeck, A.R.; Leitzmann, M.F., et al., Mediterranean dietary pattern and prediction of all-cause mortality in a US population: Results from the nih-aarp diet and health study. Arch Intern Med 2007, 167, 2461- 2468. DOI: 10.1001/archinte.167.22.2461

49. Visioli, F.; Galli, C., The role of antioxidants in the mediterranean diet. . Lipids 2001, 36, S49 -52 . DOI: 10.1007/s11745-001-0682-z

50. Ambring, A.; Friberg, P.; Axelsen, M.; Laffrenzen, M.; Taskinen, M.R.; Basu, S.; Johansson, M., Effects of a mediterranean inspired diet on blood lipids, vascular function and oxidative stress in healthy subjects. Clin Sci 2004, 106, 519-525. DOI: 10.1042/CS20030315

51. Hagfors, L.; Leanderson, P.; Skoldstam, L.; Andersson, J.; Johansson, G., Antioxidant intake, plasma antioxidants and oxidative stress in a randomized, controlled, parallel, mediterranean dietary intervention study on patients with rheumatoid arthritis. Nutr $J$ 2003, 2, 5. DOI: 10.1186/1475-2891-2-5

52. Stachowska, E.; Wesolowska, T.; Olszewska, M.; Safranow, K.; Millo, B.; Domański, L.; Jakubowska, K.; Ciechanowski, K.; Chlubek, D., Elements of mediterranean diet improve oxidative status in blood of kidney graft recipients.

Br J Nutr 2005, 93, 345-352. DOI: $\underline{10.1079 / B J N 20051374}$

53. Fitó, M.; Guxens, M.; Corella, D.; Sáez, G.; Estruch, R.; de la Torre, R.; Francés, F.; Cabezas, C.; López-Sabater, M.d.C.; Marrugat, J., et al., Effect of a traditional mediterranean diet on lipoprotein oxidation: A randomized controlled trial. . Arch Intern Med 2007, 167, 1195-1203. DOI: 10.1001/archinte.167.11.1195

54. Dai, J.; Miller, A.H.; Bremner, J.D.; Goldberg, J.; Jones, L.; Shallenberger, L.; Buckham, R.; Murrah, N.V.; Veledar, E.; Wilson, P.W., et al., Adherence to the mediterranean diet is inversely associated with circulating interleukin-6 among middleaged men: A twin study. Circulation 2008, $117, \quad 169 \quad-175 . \quad$ DOI: 10.1161/CIRCULATIONAHA.107.710699

55. Boskou, D.; Simopoulos, A.P.; Visiol, F., Olive oil. In mediterranean diets. World Rev. Nutr. Diet. 2000, 87, 56-77.

56. Visioli, F.; Poli, A.; Gall, C., Antioxidant and other biological activities of phenols from olives and olive oil. Med. Res. Rev. 2002, 22, 65-75. DOI: 10.1002/med.1028

57. Simopoulos, A.P.; Visioli, F., Mediterranean diets. . World Rev. Nutr. Diet. 2000, 87, 1-184.

58. de Lorgeril, M.; Renaud, S.; Mamelle, N.; Salen, P.; Martin, J.L.; Monjaud, I.; Guidollet, J.; Touboul, P.; Delaye, J., Mediterranean alpha-linolenic acid-rich diet in the secondary prevention of coronary heart disease. . Lancet 1994, 343, 14541459. DOI: $10.1016 / \mathrm{S} 0140-6736(94) 92580-$ 1

59. Renaud, S.; de Lorgeril, M.; Delaye, J.; Guidollet, J.; Jacquard, F.; Mamelle, N.; Martin, J.L.; Monjaud, I.; Salen, P.; Touboul, P., Cretan mediterranean diet for prevention of coronary heart disease. Am. $J$. Clin. Nutr. 1995, 61 1360S-1367S.

60. de Lorgeril, M.; Salen, P.; Martin, J.L.; Monjaud, I.; Boucher, P.; Mamelle, N., Mediterranean dietary pattern in a randomized trial. Prolonged survival and 
possible reduced cancer rate. . Arch. Intern.

Med. 1998, 158, 1181-1187. DOI: 10.1001/archinte.158.11.1181

61. Simopoulos, A.P., The mediterranean food guide. Greek column rather than an Egyptian pyramid. . Nutr. Today 1996, 30, 54-61.

62. Simopoulos, A.P., The mediterranean diets: What is so special about the diet of Greece? The scientific evidence J. Nutr. 2001, 131, 3065-3073.

63. Machowetz, A.; Poulsen, H.E.; Gruendel, S.; Weimann, A.; Fitó, M.; Marrugat, J.; de la Torre, R.; Salonen, J.T.; Nyyssönen, K.; Mursu, J., et al., Effect of olive oils on biomarkers of oxidative DNA stress in northern and southern europlans. The Faseb Journal. 2007 2007, 21, 45-52. DOI: 10.1096/fj.06-6328com

64. Huang, D.; Ou, B.; Hampsch-Woodill, M.; Flanagan, J.A.; Prior, R.L., Highthroughput assay of oxygen radical absorbance capacity (orac) using a multichannel liquid handling system coupled with a microplate fluorescence reader in 96-well format. Journal of agricultural and food chemistry 2002, 50, 4437-4444. DOI: 10.1021/jf0201529

65. Arabbi, P.R.; Genovese, M.I.; Lajolo, F.M., Flavonoids in vegetable foods commonly consumed in Brazil and estimated ingestion by the Brazilian population. J Agric Food Chem. 2004, 52, 1124-1131. DOI: $\underline{10.1021 / \mathrm{jf0499525}}$

66. Cooke, M.S.; Evans, M.D.; Dizdaroglu, M.; Lunec, J., Oxidative DNA damage: Mechanisms, mutation, and disease. . FASEB J. 2003, 17, 1195-1214. DOI: 10.1096/fj.02-0752rev

67. Evans, M.D.; Dizdaroglu, M.; Cooke, M.S., Oxidative DNA damage and disease: Induction, repair and significance. . Mutat. Res. 2004, 567, 1-61. DOI: 10.1016/i.mrrev.2003.11.001

68. Poulsen, H.E.; Prieme, H.; Loft, S., Role of oxidative DNA damage in cancer initiation and promotion. Eur. J. Cancer Prev. 1998, 7, 9-16.
69. Kasai, H., Analysis of a form of oxidative DNA damage, 8-hydroxy-2_deoxyguanosine, as a marker of cellular oxidative stress during carcinogenesis. Mutat Res. 1997, 387, 147-163. DOI: 10.1016/S1383-5742(97)00035-5

70. Poulsen, H.E., Oxidative DNA modifications. . Exp. Toxicol. Pathol. 2005, 57, 161-169.

0.1016/j.etp.2005.05.015

71. Braga, C.; La Vecchia, C.; Franceschi, S.; Negri, E.; Parpinel, M.; Decarli, A.; Giacosa, A.; Trichopoulos, D., Olive oil, other seasoning fats, and the risk of colorectal carcinoma. . Cancer 1998, 82, 448-453.

72. Franceschi, S.; Favero, A.; Conti, E.; Talamini, R.; Volpe, R.; Negri, E.; Barzan, L.; La Vecchia, C., Food groups, oils and butter, and cancer of the oral cavity and pharynx. . Br. J. Cancer 1999, 80, 614-620. DOI: $10.1038 /$ sj.bjc.6690400

73. Boskou, D.; Simopoulos, A.P.; Visioli, F., Mediterranean diets. World Rev Nutr Diet. 2000, 87, 56-77. DOI: 10.1159/000059722

74. Aldred, S., Oxidative and nitrative changes seen in lipoproteins following exercise. Atherosclerosis 2007, 192, 1-8. DOI: 10.1016/j.atherosclerosis.2007.02.001

75. Allen, D.G.; Lamb, G.D.; Westerblad, H., Skeletal muscle fatigue: Cellular mechanisms. . Physiol Rev 2008, 88, 287332. DOI: 10.1152/physrev.00015.2007

76. Atalay, M.; Lappalainen, J.; Sen, C.K., Dietary antioxidants for the athlete. Curr Sports Med Rep 2006, 5, 182-186. DOI: 10.1097/01.CSMR.0000306504.71105.6e

77. Azzi, A.; Gysin, R.; Kempna, P.; Ricciarelli, R.; Villacorta, L.; Visarius, T.; Zingg, J.M., The role of alpha-tocopherol in preventing disease: From epidemiology to molecular events. Molecular aspects of medicine 2003, 24, 325-336. DOI: 10.1016/S0098-2997(03)00028-1

78. Barclay, J.K.; Hansel, M., Free radicals may contribute to oxidative skeletal muscle fatigue. . Can J Physiol Pharmacol 1991, 69, 279-284. 
79. Clarkson, P.M., Antioxidants and physical performance. . Critical reviews in food science and nutrition 1995, 35, 131-141. DOI: 10.1080/10408399509527692

80. Coombes, J.S.; Powers, S.K.; Rowell, B.; Hamilton, K.L.; Dodd, S.L.; Shanely, R.A.; Sen, C.K.; Packer, L., Effects of vitamin e and alphalipoic acid on skeletal muscle contractile properties. J Appl Physiol 2001, 90, 1424-1430.

81. Coombes, J.S.; Rowell, B.; Dodd, S.L.; Demirel, H.A.; Naito, H.; Shanely, R.A.; Powers, S.K., Effects of vitamin e deficiency on fatigue and muscle contractile properties. . Eur J Appl Physiol 2002, 87, 272-277. DOI: 10.1007/s00421-002-0631-3

82. Cooper, C.E.; Vollaard, N.B.; Choueiri, T.; Wilson, M.T., Exercise, free radicals and oxidative stress. Biochem Soc Trans 2002, 30, 280-285.

83. Diplock, A.T., Introduction: Markers of oxidative damage and antioxidant modulation. Free Radic Res 2000, 33, S21S26.

84. Duntas, L.H., Oxidants, antioxidants in physical exercise and relation to thyroid function. Horm Metab Res 2005, 37, 572576. DOI: $10.1055 / \mathrm{s}-2005-870425$

85. Fenster, C.P.; Weinsier, R.L.; DarleyUsmar, V.M.; Patel, R.P., Obesity, aerobic exercise, and vascular disease: The role of oxidant stress. Obes Res 2002, 10, 964-968. DOI: 10.1038/oby.2002.131

86. Jackson, M.J.; Khassaf, M.; Vasilaki, A.; McArdle, F.; McArdle, A., Vitamin e and the oxidative stress of exercise. Ann NY Acad Sci 2004, 1031, 158-168. DOI: 10.1196/annals.1331.015

87. Jackson, M.J.; Pye, D.; Palomero, J., The production of reactive oxygen and nitrogen species by skeletal muscle. J Appl Physiol 2007, 102, 1664-1670. DOI: 10.1152/ japplphysiol.01102.2006

88. Ji, L.L., Antioxidant signaling in skeletal muscle: A brief review. Exp Gerontol 2007, 42,582-593.

DOI:10.1016/j.exger.2007.03.002

89. Ji, L.L., Antioxidants and oxidative stress in exercise. . Proc Soc Exp Biol Med 1999,
222, 283-292. DOI: 10.1046/j.15251373.1999.d01-145.x

90. Ji, L.L., Exercise and oxidative stress: Role of the cellular antioxidant systems. . Exerc Sport Sci Rev 1995, 23, 135-166.

91. Kanter, M.M.; Williams, M.H., Antioxidants, carnitine, choline as putative ergogenic aids. Int J Sport Nutr 1995, 5, S120-S131.

92. Konig, D.; Wagner, K.H.; Elmadfa, I.; Berg, A., Exercise and oxidative stress: Significance of antioxidants with reference to inflammatory, muscular, systemic stress. Exerc Immunol Rev 2001, 7, 108-133.

93. Matuszczak, Y.; Farid, M.; Jones, J.; Lansdowne, S.; Smith, M.A.; Taylor, A.A.; Reid, M.B., Effects of n-acetylcysteine on glutathione oxidation and fatigue during handgrip exercise. . Muscle Nerve 2005, 32, 633-638. DOI: 10.1002/mus.20385

94. McArdle, A.; Jackson, M.J., Exercise, oxidative stress and ageing. J Anat 2000, 197, 539-541. DOI: 10.1046/j.14697580.2000.19740539.x

95. Powers, S.K.; DeRuisseau, K.C.; Quindry, J.; Hamilton, K.L., Dietary antioxidants and exercise. . J Sports Sci 2004, 22, 81-94. DOI: $10.1080 / 0264041031000140563$

96. Powers, S.K.; Hamilton, K., Antioxidants and exercise. Clin Sports Med 1999, 18, 525-536.

97. Powers, S.K.; Ji, L.L.; Leeuwenburgh, C., Exercise training-induced alterations in skeletal muscle antioxidant capacity: A brief review. . Med Sci Sports Exerc 1999, 31, 987-997.

98. Powers, S.K.; Kavazis, A.N.; DeRuisseau, K.C., Mechanisms of disuse muscle atrophy: Role of oxidative stress. Am J Physiol Regul Integr Comp Physiol 2005, 288, R337-R344. DOI: 10.1152/ajpregu.00469.2004

99. Powers, S.K.; Kavazis, A.N.; McClung, J.M., Oxidative stress and disuse muscle atrophy. J Appl Physiol 2007, 102, 23892397. DOI: 10.1152/japplphysiol.01202. 2006

100. Radak, Z.; Taylor, A.W.; Ohno, H.; Goto, S., Adaptation to exercise induced oxidative 
stress: From muscle to brain. Exerc Immunol Rev 2001, 7, 90-107.

101. Reid, M.B., Free radicals and muscle fatigue: Of ros, canaries, the ioc. . Free Radic Biol Med. 2008, 44, 169-179. DOI: 10.1016/j.freeradbiomed.2007.03.002

102. Reid, M.B., Invited review: Redox modulation of skeletal muscle contraction: What we know and what we don't. J Appl Physiol 2001, 90, 724-731.

103. Reid, M.B., Nitric oxide, reactive oxygen species, skeletal muscle contraction. . Med Sci Sports Exerc 2001, 33, 371-376.

104. Rosenfeldt, F.; Hilton, D.; Pepe, S.; Krum, H., Systematic review of effect of coenzyme Q-10 in physical exercise, hypertension and heart failure. Biofactors 2003, 18, 91-100.

105. Sen, C.K., Update on thiol status and supplements in physical exercise. Can $J$ Appl Physiol 2001, 26, S4-S12. DOI: 10.1139/h2001-037

106. Sen, C.K.; Rankinen, T.; Vaisanen, S.; Rauramaa, R., Oxidative stress after human exercise: Effect of n-acetylcysteine supplementation. . J Appl Physiol 1994, 76, 2570-2577.

107. Sharpe, P., Oxidative stress and exercise: Need for antioxidant supplementation? . $\mathrm{Br}$ J Sports Med 1999, 33, 298-299. DOI: 10.1016/S0300-483X(03)00151-3

108. Tiidus, P.M.; Houstonm, M.E., Vitamin e status and response to exercise training. . Sports Med 1995, 20, 12-23. DOI: 10.2165/00007256-199520010-00002

109. Urso, M.L.; Clarkson, P.M., Oxidative stress, exercise, antioxidant supplementation. Toxicology 2003, 189, 41-54.

DOI:10.1016/S0300483X(03)00151-3

110. Powers, S.K.; Jackson, M.J., Exercise induced oxidative stress: Cellular mechanisms and impact on muscle force production. Physiol. Rev. 2008, 88, 12431276. DOI: 10.1152/physrev.00031.2007

111. Sen, C.K.; Packer, L.; Hanninen, O., Handbook of oxidants and antioxidants in exercise. . Elsevier: Amsterdam, 2000.
112. Dalle-Donne, I.; Rossi, R.; Colombo, R.; Giustarini, D.; Milzani, A., Biomarkers of oxidative damage in human disease. . Clin Chem. 2006, 32, 601-623. DOI: 10.1373/clinchem.2005.061408

113. Papaharalambus, C.A.; Griendling, K.K., Basic mechanisms of oxidative stress and reactive oxygen species in cardiovascular injury. Trends Cardiovasc. Med. 2007, 17, 48-54. DOI: 10.1016/j.tcm.2006.11.005

114. Ogino, K.; Wang, D.H., Biomarkers of oxidative / nitrosative stress: An approach to disease prevention. . Acta Med Okayama 2007, 61, 181-189.

115. Roberts, R.A.; Laskin, D.L.; Smith, C.V.; Robertson, F.M.; Allen, E.; Doorn, J.A.; Slikker, W., Nitrative and oxidative stress in toxicology and disease. Toxicological sciences 2009, 112, 4-16. DOI:10.1093/toxsci/kfp179. Epub 2009 Aug 5

116. Piazza, J.R.; Almeida, D.M.; Dmitrieva, N.O.; Klein, L.C., Frontiers in the use of biomarkers of health in research on stress and aging. J. Gerontology: Psychological Sciences 2010, 65, 513-525. DOI: 10.1093/geronb/gbq049. Epub $2010 \mathrm{Jul} 20$

117. Hawkley, L.C.; Cacioppo, J.T., Stress and the aging immune system brain. . Behavior and Immunity 2004, 18, 114-119. DOI: 10.1016/j.bbi.2003.09.005

118. (ESCODD), E.S.C.o.O.D.D., Measurement of DNA oxidation in human cells by chromatographic and enzymic methods. Free Radical Biol. Med. 2003, 34, 10891099. DOI: 10.1016/S0891-5849(03)00041$\underline{8}$

119. Wood, S.G.; Gedik, C.M.; Vaughan, N.J.; Collins, A.R., Measurement of 8-oxodeoxyguanosine in lymphocytes, cultured cells and tissue samples by HPLC with electrochemical detection. . Methods Mol Med. 2000, 38, 171-178.

120. Valavanidis, A.; Vlachogianni, T.; Fiotakis, C., 8-hydroxy-2'-deoxyguanosine (8-ohdg): A critical biomarker of oxidative stress and carcinogenesis. Journal of Environmental Science and Health Part 2009, 27, 120-139. DOI: $10.1080 / 10590500902885684$ 
121. Bartsch, H.; Nair, J., New DNA - based biomarkers for oxidative stress and cancer chemoprevention studies. Eur. J. Cancer Prev. 2000, 36, 1229-1234. DOI: 10.1016/S0959-8049(00)00095-2

122. Helbock, H.J.; Beckman, K.B.; Shigenaga, M.K.; Walter, P.B.; Woodall, A.A.; Yeo, H.C.; Ames, B.N., DNA oxidation matters: The HPLC electrochemical detection assay of 8-oxo-deoxyguanosine and 8-oxoguanosine. Proc. Natl. Acad. Sci. 1998, 95, 288-293.

123. Matayatsuk, C.; Wilairat, P., Quantitative determination of 8-hydroxy-2'deoxyguanosine as a biomarker of oxidative stress in thalassemic patients using HPLC with an electrochemical detector. J. Anal. Chem. 2008, 63, 52-56.

124. Carbonneau, M.A.; Peuchant, E.; Sess, D.; Canioni, P.; Clerc, M., Free and bound malondialdehyde measured as thiobarbituric acid adduct by HPLC in serum and plasma. Clin. Chem. 1991, 37, 1422-1429.

125. Nielsen, F.; Mikkelsen, B.B.; Nielsen, J.B.; Andersen, H.R.; Grandjean, P., Plasma malondialdehyde as biomarker of oxidative stress: Reference interval and effects of lifestyle factors. Clin Chem. 1997, 43, 12091214.

126. Richard, M.J.; Guiraud, P.; Meo, J.; Favier, A., HPLC separation of malondialdehyde thiobarbituric acid adduct in biological materials (plasma and human cells) using a commercially available reagent. $J$. Chromatogr. 1992, 577, 9-18. DOI: $\underline{10.1016 / 0378-4347(92) 80593-\mathrm{F}}$

127. Gerritsen, W.B.; van Bovenb, W.-J.P.; Bossa, D.S.; Haasa, F.J.; van Dongenc, E.P.; Aarts, L.P., Malondialdehyde in plasma, a biomarker of global oxidative stress during mini-cabg compared to onand off-pump cabg surgery: A pilot study. Interactive CardioVascular and Thoracic Surgery 2006, 5, 27-31.

128. Bird, R.P.; Draper, H.H., Comparative studies on different methods of malonaldehyde determination. . Methods Enzymol. 1984, 105, 299-305.
129. Hensley, K.; Williamson, K.S.; Maidt, M.L.; Gabbita, S.P.; Grammas, P.; Floyd, R.A., Determination of biological oxidative stress using HPLC with electrochemical detection. J. High Resol. Chromatogr. 1999, 22, 429-437. DOI: 10.1002/(SICI)1521-4168(19990801)

130. Afzal, M.; Afzal, A.; Jones, A.; Armstrong, D., Rapid method for the quantification of GSH and GSSQ in biological samples. In: "Oxidative stress. Biomarkers and antioxidant protocols". Methods Mol Biol. 2002, 186, 117-122. DOI: 10.1385/159259-173-6:117

131. Forman, H.J.; Zhang, H.; Rinna, A., Glutathione: Overview of its protective roles, measurement and biosynthesis. . Mol. Aspects Med. 2009, 30, 1-12. DOI: 10.1016/j.mam.2008.08.006. Epub 2008 Aug 30

132. Johnson, J.M.; Strobel, F.H.; Reed, M.; Pohl, J.; Jones, D.P., A rapid lc-ftms method for analysis of cysteine, cystine and cysteine/cystine steady-steady-stateredox potential in human plasma. . Clin Chim Acta 2008, 396, 43-48. DOI: 10.1016/j.cca.2008.06.020. Epub 2008 Jun 27

133. Jones, D.P.; Carlson, J.L.; Samiec, P.S.; Sternberg, P.J.; Mody, V.C.J.; Reed, R.L.; Brown, L.A., Glutathione measurement in human plasma. Evaluation of sample collection, storage and derivatization conditions for analysis of dansyl derivatives by HPLC . Clinica Chimica Acta 1998, 275, 175-184.

DOI:10.1016/S0009-8981(98)00089-8

134. Ashfaq, S.; Abramson, J.L.; Jones, D.P.; Rhodes, S.D.; Weintraub, W.S.; Hooper, W.C.; Vaccarino, V.; Harrison, D.G.; Quyyumi, A.A., The relationship between plasma levels of oxidized and reduced thiols and early atherosclerosis in healthy adults. . J. Amer. College Cardiol. 2006, 47, 10051011. DOI: 10.1016/j.jacc.2005.09.063

135. Iyer, S.S.; Jones, D.P.; Brigham, K.L.; Rojas, M., Oxidation of plasma cysteine/cystine redox state in endotoxininduced lung injury. Am. J, Respir. Cell 
Mol. Biol. 2009, 40, 90-98. DOI: 10.1165/rcmb.2007-0447OC.

136. Miller, L.T.; Watson, W.H.; Kirlin, W.G.; Ziegler, T.R.; Jones, D.P., Oxidation of the glutathione/glutathione disulfide redox state is induced by cysteine deficiency in human colon carcinoma HT29 cells. J. Nutr. 2002, 132, 2303-2306.

137. Yamamoto, Y.; Yamashita, S., Ubiquinol/ubiquinone ratio as a marker of oxidative stress. Methods Mol Biol. 2002, 186, 241-246. DOI: 10.1385/1-59259-173$\underline{6: 241}$

138. Lankin, V.Z.; Tikhaze, A.K.; Kukharchuk, V.V.; Konovalova, G.G.; Pisarenko, O.I.; Kaminnyi, A.I.; Shumaev, K.B.; Belenkov, Y.N., Antioxidants decreases the intensification of low density lipoprotein in vivo peroxidation during therapy with statins molecular and cellular biochemistry. Mol Cell Biochem. 2003, 249, 129-140. DOI: 10.1023/A:1024742907379

139. Chrysselis, M.; Rekka, E.; Kourounakis, P., Antioxidant therapy and cardiovascular disorders. Expert Opinion on Therapeutic Patents 2001, 11, 33-43.

140. Virdis, A.; Ghiadoni, L.; Salvetti, G.; Versari, D.; Taddei, S.; Salvetti, A., Endothelial dysfunction, vascular damage and clinical events: Role of antioxidant therapy High Blood Pressure \& Cardiovascular Prevention 2004, 11, 15-27.

141. Kendall, M.J.; Nuttall, S.L., Anti-oxidant therapy for the treatment of coronary artery disease. Expert Opin Investig Drugs 1999, 8, 1763-1784. DOI: $\underline{10.1517 / 13543784.8 .11 .1763}$

142. Abrescia, P.; Golino, P., Free radicals and antioxidants in cardiovascular diseases. Expert Review of Cardiovascular Therapy 2005, 3, 159-171. DOI: 10.1046/j.13652125.1997.t01-1-00594.x

143. Castillo, R.; Rodrigo, R.; Perez, F.; Cereceda, M.; Asenjo, R.; Zamorano, J.; Navarrete, R.; Villalabeitia, E.; Sanz, J.; Baeza, C., et al., Antioxidant therapy reduces oxidative and inflammatory tissue damage in patients subjected to cardiac surgery with extracorporeal circulation.
Basic Clin Pharmacol Toxicol. 2011, 108, 256-262.

DOI:10.1111/j.17427843.2010.00651.x.

144. Meagher, E.; Rader, D.J., Antioxidant therapy and atherosclerosis - animal and human studies. Trends in Cardiovascular Medicine 2001, 11, 162-165. DOI: 10.1016/S1050-1738(01)00105-0

145. McMahon, A.C.; Duong, T.T.; Brieger, D.; Witting, P.K., Is there potential for antioxidants to enhance thrombolysis therapy in patients with ischemic stroke? Future Cardiol. 2006, 2, 659-665. DOI: $\underline{10.2217 / 14796678.2 .6 .659}$

146. Li, W.G.; Coppey, L.; Weiss, R.M.; Oskarsson, H.J., Antioxidant therapy attenuates jnk activation and apoptosis in the remote noninfarcted myocardium after large myocardial infarction. Biochem Biophys Res Commun. 2001, 280, 353-357. DOI: $10.1006 / \mathrm{bbrc} .2000 .4134$

147. Gilgun-Sherki, Y.; Melamed, E.; Offen, D., The role of oxidative stress in the pathogenesis of multiple sclerosis: The need for effective antioxidant therapy. Journal of Neurology 2004, 251, 261-268 DOI: 10.1007/s00415-004-0348-9

148. Carlson, N.G.; Rose, J.W., Antioxidants in multiple sclerosis: Do they have a role in therapy? . CNS Drugs 2006, 20, 433-441.

149. Gabriele, S.; Alberto, P.; Sergio, G.; Fernanda, F.; Marco, M.C., Emerging potentials for an antioxidant therapy as a new approach to the treatment of systemic sclerosis. Toxicology 2000, 155, 1-15. DOI: 10.1016/S0300-483X(00)00272-9

150. Akbas, H.S.; Timur, M.; Ozben, T., Concurrent use of antioxidants in cancer therapy: An update. Expert Rev Clin Immunol. 2006, 2, 931-939. DOI: 10.1586/1744666X.2.6.931.

151. Stankiewicz, A.; Skrzydlewska, E., Amifostine-antioxidant drug in anticancer therapy. Toxicol Mech Methods. 2006, 16, 181-188.

DOI: $\underline{10.1080 / 15376520500195608}$

152. Aiko, S.; Kumano, I.; Yamanaka, N.; Tsujimoto, H.; Takahata, R.; Maehara, T., Effects of an immuno-enhanced diet 
containing antioxidants in esophageal cancer surgery following neoadjuvant therapy. Diseases of the Esophagus 2012, $25, \quad 137-145$. DOI: 10.1111/j.14422050.2011.01221.x

153. İynem, A.H.; Alademir, A.Z.; Öbek, C.; Kural, A.R.; Konukoglu, D.; Akçay, T., The effect of prostate cancer and antianrogenic therapy on lipid peroxidation and antioxidant systems. International Urology and Nephrology 2003, 36, 57-62.

154. Gadjeva, V.; Dimov, A.; Georgieva, N., Influence of therapy on the antioxidant status in patients with melanoma Journal of Clinical Pharmacy \& Therapeutics 2008, 33, 179-185. DOI: 10.1111/j.13652710.2008.00909.x

155. Strokov, I.A.; Manukhina, E.B.; Bakhtina, L.Y.; Malyshev, I.Y.; Zoloev, G.K.; Kazikhanova, S.I.; Ametov, A.S., The function of endogenous protective systems in patients with insulin-dependent diabetes mellitus and polyneuropathy: Effect of antioxidant therapy. Bulletin of Experimental Biology and Medicine 2000, 130, 986-990. DOI: 10.1023/A:1002874125993

156. Ros, R.D.; Assaloni, R.; Ceriello, A., Antioxidant therapy in diabetic complications: What is new? . Current Vascular Pharmacology 2004, 2, 335-341. DOI: $10.2174 / 1570161043385538$

157. Inoguchi, T.; Tsubouchi, H.; Etoh, T.; Kakimoto, M.; Sonta, T.; Utsumi, H.; Sumimoto, H.; Yu, H.Y.; Sonoda, N.; Inuo, M., et al., A possible target of antioxidative therapy for diabetic vascular complicationsvascular nad(p)h oxidase. Current Medicinal Chemistry 2003, 10, 1759-1764.

158. Kowluru, R.; Engerman, R.; Kern, T., Diabetes-induced metabolic abnormalities in myocardium: Effect of antioxidant therapy. Free Radical Research 2000, 32, 67-74. DOI: $10.1080 / 10715760000300071$

159. Ziegler, D., Therapy with antioxidants in human diabetic neuropathy Journal of Neurochemistry 2003, 85, 15. DOI: 10.1046/j.1471-4159.85.s2.14_5.x
160. Makuc, J.; Petrovič, D., A review of oxidative stress related genes and new antioxidant therapy in diabetic nephropathy. Cardiovasc Hematol Agents Med Chem. 2011, 9, 253-261.

161. Tan, D.-X.; Manchester, L.C.; Sainz, R.; Mayo, J.C.; Alvares, F.L.; Reiter, R.J., Antioxidant strategies in protection against neurodegenerative disorders. Expert Opinion on Therapeutic Patents 2003, 13, 1513-1543.

DOI: $\underline{10.1517 / 13543776.13 .10 .1513}$

162. Rao, A.V.; Balachandran, B., Role of oxidative stress and antioxidants in neurodegenerative diseases. Nutr Neurosci 2002, $5, \quad 291-309$. DOI: 10.1080/1028415021000033767

163. Contestabile, A., Antioxidant strategies for neurodegenerative diseases. Expert Opinion on Therapeutic Patents 2001, 11, 573-585. DOI: $10.1517 / 13543776.11 .4 .573$

164. Hajieva, P.; Behl, C., Antioxidants as a potential therapy against age-related neurodegenerative diseases: Amyloid beta toxicity and Alzheimers disease. Current Pharmaceutical Design 2006, 12, 699-704. DOI: $10.2174 / 138161206775474297$

165. G., A.; Obrenovich, M.E.; Reddy, V.P.; Shenk, J.C.; Moreira, P.I.; Nunomura, A.; Zhu, X.; Smith, M.A.; Perry, G., Antioxidant therapy in Alzheimer's disease: Theory and practice. Mini Rev Med Chem. 2008, $8, \quad 1395-1406 . \quad$ DOI: $\underline{10.2174 / 138955708786369582}$

166. Fydrych, A.; Moir, R.D.; Huang, C.; Shi, Y.; Rogers, J.T.; Huang, X., Amyloidtargeted metal chelation, anti-oxidative stress, and anti- inflammation as potential Alzheimers therapies Current Bioactive Compounds 2008, 4, 140-149. DOI: $\underline{10.2174 / 157340708786305989}$

167. Liu, Q.; Xie, F.; Rolston, R.; Moreira, P.I.; Nunomura, A.; Zhu, X.; Smith, M.A.; Perry, G., Prevention and treatment of Alzheimer disease and aging: Antioxidants. Mini Rev Med Chem. 2007, 7, 171-180. DOI: $10.2174 / 138955707779802552$

168. Ebadi, M.; Srinivasan, S.K.; Baxi, M.D., Oxidative stress and antioxidant therapy in 
Parkinson's disease Progress in Neurobiology 1996, 48, 1-19. DOI: 10.1016/0301-0082(95)00029-1

169. Costello, D.J.; Delanty, N., Oxidative injury in epilepsy: Potential for antioxidant therapy? Expert Rev Neurother. 2004, 4, 541-553. DOI: 10.1586/14737175.4.3.541

170. Victor, V.M.; Rocha, M.; Esplugues, J.V.; Fuente, M.D.l., Role of free radicals in sepsis: Antioxidant therapy. Current Pharmaceutical Design 2005, 11, 31413158. DOI: 10.2174/1381612054864894

171. Rinaldi, S.; Landucci, F.; De Gaudio, A.R., Antioxidant therapy in critically septic patients Current Drug Targets 2009, 10, 872880.

DOI:10.2174/138945009789108774

172. Rocha, M.; Herance, R.; Rovira, S.; Hernandez-Mijares, A.; Victor, V.M., Mitochondrial dysfunction and antioxidant therapy in sepsis infectious disorders. Drug Targets 2012, 12, 161-178. DOI: 10.2174/187152612800100189

173. Batra, S.; Kumar, R.; Kapoor, A.K.; Ray, G., Alterations in antioxidant status during neonatal sepsis. Ann Trop Paediatr. 2000, 20, 27-33.

174. Rosario, A.L.; Azevedo, L.C.P., Therapeutic use of antioxidants in sepsis Recent Patents on Endocrine, Metabolic \& Immune Drug Discovery 2007, 1, 210-223.

175. Jaswal, S.; Mehta, H.C.; Sood, A.K.; Kaur, J., Antioxidant status in rheumatoid arthritis and role of antioxidant therapy. Clinica Chimica Acta 2003, 338, 123-129. DOI: 10.1016/j.ccen.2003.08.011

176. Michael, J.F., Vitamin e as a protective antioxidant in progressive renal failure Nephrology 2000, 5, 1-7. DOI: 10.1159/000012784

177. Amann, K.; Törnig, J.; Buzello, M.; Kuhlmann, A.; Gross, M.L.; Adamczak, M.; Buzello, M.; Ritz, E., Effect of antioxidant therapy with dl-alphatocopherol on cardiovascular structure in experimental renal failure. Kidney Int. 2002, 62 , 877-884. DOI: $10.1046 / \mathrm{j} .1523-$ 1755.2002.00518.x
178. Chrzanowska, M.; Kamińska, J.; Głyda, M.; Duda, G.; Makowska, E., Antioxidant capacity in renal transplant patients. Die Pharmazie 2010, 65, 363-366.

179. Medina, J.; Moreno-Otero, R., Pathophysiological basis for antioxidant therapy in chronic liver disease. Drugs 2005, 65, 2445-2461.

180. Look, M.P.; Gerard, A.; Rao, G.S.; Sudhop, T.; Fischer, H.; Sauerbruch, T.; Spengler, U., Interferon/antioxidant combination therapy for chronic hepatitis c--a controlled pilot trial. Antiviral Res. 1999, 43, 113-122. DOI: 10.1016/S0166-3542(99)00041-8

181. Misso, N.L.A.; Thompson, P.J., Oxidative stress and antioxidant deficiencies in asthma: Potential modification by diet Redox Report 2005, 10, 247-255. DOI: 10.1179/135100005X70233

182. Riccioni, G.; D’Orazio, N., The role of selenium, zinc and antioxidant vitamin supplementation in the treatment of bronchial asthma: Adjuvant therapy or not? Expert Opinion on Investigational Drugs 2005, $14, \quad 1145-1155$. DOI: 10.1517/13543784.14.9.1145

183. Kumar, S.S.; Shanmugasundaram, K.R., Amrita bindu-an antioxidant inducer therapy in asthma children Journal of Ethnopharmacology 2004, 90, 105-114. DOI: 10.1016/j.jep.2003.09.031

184. Christofidou-Solomidou, M.; Muzykantov, V.R., Antioxidant strategies in respiratory medicine. Treat Respir Med. 2006, 5, 4778.

185. Langmead, L.; Dawson, C.; Hawkins, C.; Banna, N.; Loo, S.; Rampton, D.S., Antioxidant effects of herbal therapies used by patients with inflammatory bowel disease: An in vitro study. Alimentary Pharmacology \& Therapeutics 2002, 16, 197205.DOI:10.1046/j.13652036.2002.011 57.x

186. Horton, J.W., Free radicals and lipid peroxidation mediated injury in burn trauma: The role of antioxidant therapy. Toxicology 2003, 189, 75-88. DOI: $\underline{0.1016 / \mathrm{S} 0300-483 \mathrm{X}(03) 00154-9}$ 
187. Sekhon, L.H.; Gupta, S.; Kim, Y.; Agarwal, A., Current women's health reviews. Female Infertility and Antioxidants 2010, 6, 84-95.

188. John, A.R., The role of sperm oxidative stress in male infertility and the significance of oral antioxidant therapy. Human Reproduction 2011, 26, 1628-1640. DOI: 10.1093/humrep/der132. Epub 2011 May 5

189. Staal, F., Antioxidant therapy for aids. European Journal of Clinical Investigation 2000, 30, 841-843. DOI: 10.1046/j.13652362.2000.00728.x

190. Sepulveda, R.T.; Watson, R.R., Treatment of antioxidant deficiencies in aids patients Nutrition Research 2002, 22, 27-37. DOI: $\underline{10.1016 / \mathrm{S} 0271-5317(01) 00355-4}$

191. Leng, G.C.; Lee, A.J.; Fowkes, F.G.R.; Deary, I.J.; Horrobin, D., Impact of antioxidant therapy on symptoms of anxiety and depression. A randomized controlled trial in patients with peripheral arterial disease. Journal of Nutritional \& Environmental Medicine 1998, 8, 321-328. DOI: 10.1080/13590849861899

192. Chayasirisobhon, S., Use of a pine bark extract and antioxidant vitamin combination product as therapy for migraine in patients refractory to pharmacologic medication headache. The Journal of Head and Face Pain 2006, 46, 788-793. DOI: 10.1111/j.1526-4610.2006.00454.X

193. Ramos-Marquez, M.E.; Siller-Lopez, F., Current antioxidant molecular therapies for oxidative stress-related ailments Current Gene Therapy 2008, 8, 256-263. DOI: $\underline{10.2174 / 156652308785160665}$

194. Gordon, C.A.; Himmelfarb, J., Antioxidant therapy in uremia: Evidence-based medicine? Seminars in Dialysis 2004, 17, 327332.

DOI:10.1111/j.08940959.2004.17357.x

195. Perrone, S.; Turrisi, G.; Buonocore, G., Antioxidant therapy and neuroprotection in the newborn. Pediatric Health 2008, 2, 715732.

196. Cuzzocrea, S.; Thiemermann, C.; Salvemini, D., Potential therapeutic effect of antioxidant therapy in shock and inflammation. Current Medicinal Chemistry 2004, 11, 1147-1162. DOI: $\underline{10.2174 / 0929867043365396}$

197. Virlos, I.T.; Mason, J.; Schofield, D.; McCloy, R.F.; Eddleston, J.M.; Siriwardena, A.K., Intravenous nacetylcysteine, ascorbic acid and seleniumbased anti-oxidant therapy in severe acute pancreatitis scandinavian. Journal of Gastroenterology 2003, 38, 1262-1267. DOI: 10.1080/00365520310006540

198. Heaney, A.P.; Sharer, N.; Braganza, J.M.; Durrington, P.N., Prevention of acute pancreatitis induced by marked hypertriglyceridaemia in familial lipoprotein lipase deficiency with high dose antioxidant therapy. Atherosclerosis 1997, $135,136$. 